\title{
ТОЧНОСТЬ ПРЕДИКЦИИ ПИГМЕНТАЦИИ ВОЛОС И ГЛАЗ ПО ГЕНЕТИЧЕСКИМ МАРКЕРАМ для пОпУляций РОссии
}

О. П. Балановский ${ }^{1,2,3}$, В. С. Петрушенко $1,2,4$, И. О. Горин ${ }^{1,2,4}$, Ж. А. Кагазежева ${ }^{1,2}$, Н. В. Маркина², Е. С Кострюкова ${ }^{5}$, Н. А. Лейбова ${ }^{6}$ А. М. Маурер ${ }^{7}$, Е. В. Балановская ${ }^{1,3} \bowtie$

${ }^{1}$ Медико-генетический научный центр, Москва, Россия

2 Институт общей генетики имени Н. И. Вавилова Российской академии наук, Москва, Россия

${ }^{3}$ Биобанк Северной Евразии, Москва, Россия

${ }^{4}$ Московский физико-технический институт (Научно-исследовательский университет), Москва, Россия

${ }_{5}^{5}$ Федеральный научно-клинический центр физико-химической медицины, Москва, Россия

${ }^{6}$ Институт этнологии и антропологии Российской академии наук, Москва, Россия

7 Научно-исследовательский институт и музей антропологии имени Д. Н. Анучина, Москва, Россия

Предикция цвета глаз и волос по генотипу становится распространенным инструментом в судебно-медицинской экспертизе и в исследованиях древних популяций. Для этого широко используется панель HlrisPlex-S, разработанная на выборке голландцев и верифицированная для некоторых других популяций Западной Европы. Однако точность ее предсказаний для представителей других регионов мира не изучена. Особый интерес представляют популяции России, в которых (в отличие от большинства других популяций мира) присутствуют не только темные, но и светлые оттенки цвета волос и глаз. Целью работы было определить точность предикции цвета глаз и волос для популяций России. Мы изучили 144 представителя коренного населения России (аварцев, алеутов, бурят, ительменов, карел, коряков, марийцев, нанайцев, русских, рутульцев, чувашей, чукчей, эвенков, эвенов). Для всех индивидов были сделаны антропологические фотографии. На основании фотографий эксперты-антропологи проводили определение цвета глаз и волос. Для тех же индивидов проводили генотипирование SNP-маркеров панели HIrisPlex. На основании генотипов предсказывали фенотипь и предсказанные фенотипы сопоставляли с реальными. Получена серия показателей точности HIrisPlex для популяций Европейской части России и Сибири. В целом точность оказалась удовлетворительной, хотя и несколько сниженной по сравнению с точностью для популяций Западной Европы. В будущих исследованиях возможно провести поиск дополнительных маркеров, повышающих точность предикции для популяций России.

Ключевые слова: цвет глаз, цвет волос, генетические маркеры, предикция, генофонд, коренное население, HIrisPlex-S

Финансирование: исследование выполнено при финансовой поддержке Министерства науки и образования РФ (Госконтракт № 011-17 от 26.09.2017) в рамках научно-технической программы Союзного государства «ДНК-идентисикация» (работы по генотипированию, по фенотипированию европейских образцов, подготовке текста статьи) и Государственного задания Министерства науки и высшего образования РФ для Медико-генетического научного центра им. академика Н. П. Бочкова (работы по фенотипированию сибирских образцов, созданию базы данных, анализу данных).

Благодарности: благодарим всех доноров образцов. Коллекция ДНК и антропологических фотографий предоставлена АНО «Биобанк Северной Евразии». Информация о вкладе авторов: Е. В. Балановская - дизайн и руководство исследованием; В. С. Петрушенко и И. О. Горин - биоинформатический анализ и анализ литературы, написание текста статьи; А. М. Маурер, Н. А. Лейбова - фенотипирование образцов; Ж. А. Кагазежева - фенотипирование образцов, фотографирование и обработка фотографий, работа с табличными данными; О. П. Балановский и Н. В. Маркина - написание текста статьи; Е. С. Кострюкова - генотипирование.

Соблюдение этических стандартов: исследование одобрено этическим комитетом Медико-генетического научного центра (протокол № 3/1 от 5 сентября 2018 г.), выполнено на образцах, полученных в ходе популяционно-генетического обследования генофонда; все обследуемые подписали добровольное информированное согласие.

$\bowtie$ Для корреспонденции: Елена Владимировна Балановская

ул. Москворечье, д. 1, Медико-генетический научный центр, г. Москва, 115522; balanovska@mail.ru

Статья получена: 22.10.2019 Статья принята к печати: 26.10.2019 Опубликована онлайн: 28.10.2019

DOI: 10.24075/vrgmu.2019.069

\section{THE ACCURACY OF PREDICTING EYE AND HAIR PIGMENTATION BASED ON GENETIC MARKERS IN RUSSIAN POPULATIONS}

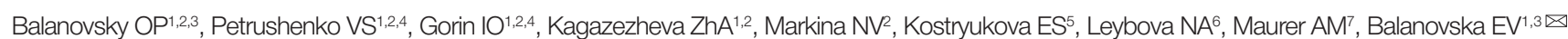

${ }^{1}$ Research Centre for Medical Genetics, Moscow, Russia

2 Vavilov Institute of General Genetics, Moscow, Russia

${ }^{3}$ Biobank of North Eurasia, Moscow, Russia

${ }^{4}$ Moscow Institute of Physics and Technology, Moscow, Russia

${ }^{5}$ Federal Research and Clinical Center of Physical-Chemical Medicine, Moscow, Russia

${ }^{6}$ Institute of Anthropology and Ethnography, Moscow, Russia

${ }^{7}$ Anuchin Research Institute and Museum of Anthropology, Moscow, Russia

Prediction of eye and hair color from DNA is being increasingly employed in forensic medicine and the studies of ancient populations. HIrisPlex-S is a prediction tool that was developed using the data collected from Dutch donors and verified for some other European populations. The accuracy of its predictions for other world populations has not been studied yet. Unlike the majority of other world populations, Russian populations are characterized not only by dark but also by light color eyes and hair and therefore pose a special interest in this respect. The aim of this work was to determine the accuracy of eye and hair color predictions for Russian populations. We studied 144 representatives of indigenous populations of Russia (Avars, Aleuts, Buryats, Itelmens, Karelians, Koryaks, Maris, Nanais, Russians, Rutulians, Chuvashes, Chukchi, Evenks, and Evens). Anthropological photos were taken of all individuals. Based on the photos, the anthropologists identified eye and hair color phenotypes. SNP-markers were genotyped using the HrisPlex panel. Based on the genotypes, the phenotypes were predicted and subsequently compared to the actual phenotypes. We obtained a series of HirisPlex accuracy indicators for the populations inhabiting the European part of Russia and Siberia. On the whole, prediction accuracy was satisfactory, although a bit lower than for West European populations. Further research could look for additional markers increasing the accuracy of predictions for Russian populations.

Keywords: eye color, hair color, genetic markers, prediction, gene pool, indigenous people, HirisPlex-S

Funding: the study was supported by the Ministry of Science and Education of the Russian Federation (State contract 011-17 dated 26.09.2017) as part of the Union State Research and Technical Project DNA-based identification, which included genotyping and phenotyping of European samples and preparation of this manuscript, and the State assignment of the Ministry of Science and Higher Education of the Russian Federation for the Research Centre for Medical Genetics (phenotyping of Siberian samples, creating a database, data analysis).

Acknowledgements: we thank all donors participating in our study. DNA samples and anthropological images were provided by the Biobank of North Eurasia.

Author contribution: Balanovska EV — supervision and study design; Petrushenko VS, Gorin IO — bioinformatic analysis, literature analysis, manuscript preparation; Maurer AM, Leybova NA — phenotyping of the samples; Kagazezheva ZhA — phenotyping of the samples, photography, photo processing, tabular data processing; Balanovsky OP, Markina NV — manuscript preparation; Kostryukova ES — genotyping.

Compliance with ethical standards: the study was approved by the Ethics Committee of the Research Centre for Medical Genetics (Protocol No $3 / 1$ dated September 5 , 2018). The samples used in this work were obtained from a population genetic study. Informed consent was obtained from all study participants.

$\triangle$ Correspondence should be addressed: Elena V. Balanovska

Moskvorechie, 1, Research Centre for Medical Genetics, Moscow, 115522; balanovska@mail.ru

Received: 22.10.2019 Accepted: 26.10.2019 Published online: 28.10.2019

DOI: 10.24075/brsmu.2019.069 
В течение последней декады определение вероятного цвета глаз и волос по ДНК стало важной частью судебномедицинских и популяционно-генетических исследований, поскольку позволяет определить вероятную внешность человека, информация о котором ограничена его биологическим образцом. Такое определение используют при поиске правонарушителей, идентификации жертв катастроф, при изучении образцов ДНК из древних популяций, в генетической генеалогии и других областях исследований. Во множестве исследований [1-10] выявлены некоторые ключевые гены и сайты внутри этих генов, вовлеченные в фенотипы по пигментации. Наиболее важные сайты были включены в HIrisPlex-систему и ee расширенный вариант HlrisPlex-S, позволяющий определять и вероятный цвет кожи [8-11]. Генотипирование 25 маркеров (SNP и инделы) [10] помогает быстро и надежно предсказывать цвет глаз и волос (HlrisPlex); дополнительные 16 маркеров предсказывают также цвет кожи (HlrisPlex-S).

При публикации этой системы предикции пигментации по генотипу [8-11] показано, что такое предсказание надежно для популяций европейского происхождения, однако эту систему и разрабатывали на образцах из европейских популяций, в основном для голландцев (верификация проведена на населении Польши, Греции и Ирландии). Точность HIrisPlex для популяций из других регионов мира не проверяли. Конечно, для населения большинства других континентов проверка этой системы не информативна, поскольку большинство неевропейских популяций имеют только темные глаза и темные волосы. Но в некоторых популяциях из пограничных регионов между Европой и Азией (например, Алтая, Кавказа, Зауралья) распространен как темный, так и светлый фенотип глаз/волос. При этом они генетически значительно отличаются от западных европейцев [12], а значит, могут отличаться и по спектру генетических маркеров, определяющих степень пигментации. Даже популяции из уральского региона, генетически более близкие к западноевропейцам, чем популяции Кавказа и Западной Сибири, все же генетически значительно более удалены от голландцев, чем ирландцы, поляки и греки, образцы которых использовали для верификации HIrisPlex.

Целью работы было в ходе экспедиционных обследований коренного населения и фотографирования индивидов оценить предсказательную силу системы HIrisPlex-S для цвета глаз и волос на различных популяциях Северной Евразии.

\section{ПАЦИЕНТЫ И МЕТОДЫ}

\section{Сбор образцов и фенотипирование}

В ходе экспедиционных обследований генофондов, проводимых нашим научным коллективом [13], были сделаны антропологические фотографии представителей коренного населения различных народов России и сопредельных стран. Обследование популяций, включенных в настоящее исследование, проводили в ходе нескольких полевых выездов в 2015-2019 гг. Критериями включения в исследование были: 1) возраст старше 18 лет; 2) самоидентисикация четырех предков обследуемого (двух дедушек и двух бабушек) как принадлежащих к данному народу; 3) наличие антропологической фотографии обследуемого; 4) наличие письменного информированного согласия на участие в обследовании. Критерии исключения: 1) недостаточное качество фотографий, не позволяющее надежно определить цвет глаз и волос; 2) отсутствие полного просиля генотипированных маркеров.

В результате применения данных критериев в исследование включили 144 индивидуума из следующих популяций:

1) Европейская часть России - русские, марийцы, чуваши, карелы, рутульцы, аварцы $(n=66$, из них 65 мужчин и 1 женщина);

2) Сибирь и Дальний Восток - буряты, эвенки, эвены, нанайцы, коряки, ительмены, чукчи, алеуты ( $n=78$, из них 45 мужчин и 33 женщины).

Фенотипы цвета глаз и волос определяли по фотографиям три эксперта: двое - физические антропологи с большим опьтом фенотипирования, третий генетик, специально обученный фенотипированию. Все эксперты выполняли фенотипирование независимо, и в тех случаях, когда определенные ими фенотипы различались, проводили тщательное совместное определение до достижения консенсусной оценки. Цвет глаз - темный, светлый или смешанный - был успешно определен для вcex 144 индивидов. Цвет волос был определен для меньшего числа образцов в связи с невозможностью определения натурального цвета волос женщин по фотографиям, а также наличия некоторого числа мужчин с сединой или облысением. Результаты фенотипирования представлены в табл. 1.

\section{Генотипирование и предикция цвета глаз и волос по генотипу}

ДНК из образцов крови или слюны выделяли классическим методом фенол-хлороформной экстракции [14]. Генотипирование проводили на основе использования биочипа Infinium Omni5Exome-4 v1.3 BeadChip (Illumina; США) на платформе iScan. Качество оценивали c помощью рекомендованного производителем программного обеспечения GenomeStudio v2.0. (Illumina; США). Для всех образцов интегральная оценка качества (CR - CallRate) составила выше 0,99, что говорит о пригодности полученных результатов для дальнейшей обработки. Использованная панель включает более 4 млн SNP-маркеров, поэтому полученные результаты применяют в целом ряде исследований. В рамках данного исследования из этого массива данных были извлечены генотипы по 29 маркерам, входящим в панель HlrisPlex и используемым для предсказания цвета глаз, волос и кожи. Всего в HIrisPlex-S 25 маркеров цвета глаз и волос и 16 маркеров цвета кожи. Из этих маркеров нами успешно генотипированы 19 маркеров предсказания цвета глаз и волос и 10 маркеров, по которым предсказывают цвет кожи. Панель HlrisPlex допускает использование неполного профиля генотипирования (ключевое значение имеют несколько обязательных маркеров, остальные лишь немного увеличивают точность предикции), поэтому использование 19 маркеров из 25 достаточно для качественной предикции с помощью HIrisPlex (маркеры для предсказания цвета кожи не были учтены в нашем исследовании). Пояснения требует обработка пропущенных генотипов только по одному маркеру rs312262906. При использовании системы HIrisPlex-S без этого маркера были получены предсказания только цвета глаз, но не цвета волос. Данный полиморфизм приводит к сдвигу рамки считывания в гене MC1R и ассоциирован 
Таблица 1. Фенотипы (цвет глаз и волос), определенные по антропологическим фотографиям

\begin{tabular}{|c|c|c|c|c|c|c|}
\hline Образец & Метапопуляция & Этнос & Пол & Возраст на момент сбора & Цвет волос & Цвет глаз \\
\hline FES-0001 & Сибирь & эвенки & M & 63 & не анализируется & темный \\
\hline FES-0002 & Сибирь & нанайцы & M & 33 & темные & темный \\
\hline FES-0003 & Сибирь & нанайцы & M & 42 & темные & темный \\
\hline FES-0004 & Сибирь & нанайцы & M & 29 & темные & темный \\
\hline FES-0005 & Сибирь & нанайцы & M & 58 & темные & темный \\
\hline FES-0006 & Сибирь & нанайцы & M & 62 & темные & светлый \\
\hline FES-0007 & Сибирь & нанайцы & M & 68 & темные & темный \\
\hline FES-0008 & Сибирь & нанайцы & M & 64 & не анализируется & темный \\
\hline FES-0009 & Сибирь & нанайцы & M & 52 & темные & темный \\
\hline FES-0010 & Сибирь & нанайцы & M & 55 & темные & темный \\
\hline FES-0011 & Сибирь & нанайцы & M & 46 & не анализируется & темный \\
\hline FES-0012 & Сибирь & нанайцы & M & 51 & темные & темный \\
\hline FES-0013 & Сибирь & эвены & M & 52 & промежуточные & светлый \\
\hline FES-0014 & Сибирь & эвены & M & 21 & темные & светлый \\
\hline FES-0015 & Сибирь & эвены & M & 39 & темные & темный \\
\hline FES-0016 & Сибирь & эвены & M & 21 & темные & темный \\
\hline FES-0017 & Сибирь & эвены & M & 20 & темные & темный \\
\hline FES-0018 & Европейская часть России & башкиры & M & 64 & не анализируется & темный \\
\hline FES-0019 & Сибирь & буряты & M & 76 & не анализируется & темный \\
\hline FES-0020 & Сибирь & буряты & M & 68 & не анализируется & темный \\
\hline FES-0021 & Сибирь & буряты & M & 50 & темные & темный \\
\hline FES-0022 & Сибирь & буряты & M & 68 & темные & темный \\
\hline FES-0023 & Европейская часть России & чуваши & M & 33 & промежуточные & светлый \\
\hline FES-0024 & Европейская часть России & чуваши & M & 51 & светлые & светлый \\
\hline FES-0025 & Европейская часть России & чуваши & M & 53 & промежуточные & светлый \\
\hline FES-0026 & Европейская часть России & чуваши & M & 42 & темные & светлый \\
\hline FES-0027 & Европейская часть России & чуваши & M & 41 & темные & темный \\
\hline FES-0028 & Европейская часть России & чуваши & M & 36 & рыжие & светлый \\
\hline FES-0029 & Европейская часть России & чуваши & M & 55 & не анализируется & темный \\
\hline FES-0030 & Европейская часть России & чуваши & M & 45 & темные & темный \\
\hline FES-0031 & Европейская часть России & чуваши & M & 33 & рыжие & темный \\
\hline FES-0032 & Европейская часть России & чуваши & M & 46 & промежуточные & темный \\
\hline FES-0033 & Европейская часть России & чуваши & M & 32 & промежуточные & темный \\
\hline FES-0034 & Европейская часть России & чуваши & M & 41 & не анализируется & светлый \\
\hline FES-0035 & Европейская часть России & чуваши & M & 49 & промежуточные & темный \\
\hline FES-0036 & Европейская часть России & чуваши & M & 53 & не анализируется & темный \\
\hline FES-0037 & Европейская часть России & чуваши & M & 46 & промежуточные & темный \\
\hline FES-0038 & Европейская часть России & чуваши & M & 57 & темные & темный \\
\hline FES-0039 & Европейская часть России & чуваши & M & 42 & не анализируется & светлый \\
\hline FES-0040 & Европейская часть России & чуваши & M & 47 & рыжие & светлый \\
\hline FES-0041 & Европейская часть России & чуваши & M & 23 & промежуточные & светлый \\
\hline FES-0042 & Европейская часть России & аварцы & M & 52 & не анализируется & темный \\
\hline FES-0043 & Европейская часть России & аварцы & M & 55 & не анализируется & светлый \\
\hline FES-0044 & Европейская часть России & аварцы & M & 20 & промежуточные & светлый \\
\hline FES-0045 & Европейская часть России & рутульцы & M & 36 & не анализируется & темный \\
\hline FES-0046 & Европейская часть России & рутульцы & M & 38 & темные & темный \\
\hline FES-0047 & Европейская часть России & рутульцы & M & 83 & не анализируется & темный \\
\hline FES-0048 & Европейская часть России & рутульцы & M & 57 & не анализируется & темный \\
\hline FES-0049 & Европейская часть России & рутульцы & M & 55 & темные & темный \\
\hline FES-0050 & Европейская часть России & рутульцы & M & 56 & темные & темный \\
\hline FES-0051 & Европейская часть России & рутульцы & M & 65 & не анализируется & темный \\
\hline FES-0052 & Сибирь & эвены & ж & 46 & не анализируется & темный \\
\hline
\end{tabular}


Продолжение таблицы

\begin{tabular}{|c|c|c|c|c|c|c|}
\hline Образец & Метапопуляция & Этнос & Пол & Возраст на момент сбора & Цвет волос & Цвет глаз \\
\hline FES-0053 & Сибирь & коряки & ж & 74 & не анализируется & темный \\
\hline FES-0054 & Сибирь & эвены & M & 50 & темные & темный \\
\hline FES-0055 & Сибирь & эвены & ж & 18 & не анализируется & темный \\
\hline FES-0056 & Сибирь & эвены & ж & 56 & не анализируется & темный \\
\hline FES-0057 & Сибирь & эвены & ж & 51 & не анализируется & темный \\
\hline FES-0058 & Сибирь & чукчи & ж & 47 & не анализируется & темный \\
\hline FES-0059 & Сибирь & коряки & ж & 68 & не анализируется & темный \\
\hline FES-0060 & Сибирь & ительмены & ж & 56 & не анализируется & темный \\
\hline FES-0061 & Сибирь & коряки & ж & 56 & не анализируется & темный \\
\hline FES-0062 & Сибирь & коряки & ж & 34 & не анализируется & темный \\
\hline FES-0063 & Сибирь & эвены & M & 63 & не анализируется & темный \\
\hline FES-0064 & Сибирь & эвены & ж & 66 & не анализируется & темный \\
\hline FES-0065 & Сибирь & камчадалы & ж & 82 & не анализируется & темный \\
\hline FES-0066 & Сибирь & ительмены & M & 62 & промежуточные & темный \\
\hline FES-0067 & Сибирь & ительмены & ж & 53 & не анализируется & темный \\
\hline FES-0068 & Сибирь & алеуты & ж & 66 & не анализируется & темный \\
\hline FES-0069 & Сибирь & алеуты & ж & 35 & не анализируется & темный \\
\hline FES-0070 & Сибирь & алеуты & M & 42 & темные & темный \\
\hline FES-0071 & Сибирь & алеуты & ж & 72 & не анализируется & темный \\
\hline FES-0072 & Сибирь & алеуты & ж & 69 & не анализируется & темный \\
\hline FES-0073 & Сибирь & алеуты & M & 63 & темные & темный \\
\hline FES-0074 & Сибирь & алеуты & ж & 53 & не анализируется & темный \\
\hline FES-0075 & Сибирь & коряки & M & 59 & не анализируется & темный \\
\hline FES-0076 & Сибирь & коряки & $M$ & 62 & темные & темный \\
\hline FES-0077 & Сибирь & чукчи & ж & 69 & не анализируется & темный \\
\hline FES-0078 & Сибирь & коряки & M & 69 & темные & темный \\
\hline FES-0079 & Сибирь & коряки & M & 43 & темные & светлый \\
\hline FES-0080 & Сибирь & коряки & $M$ & 55 & темные & темный \\
\hline FES-0081 & Сибирь & коряки & ж & 52 & не анализируется & темный \\
\hline FES-0082 & Сибирь & коряки & ж & 55 & не анализируется & темный \\
\hline FES-0083 & Сибирь & эвены & ж & 55 & не анализируется & темный \\
\hline FES-0084 & Сибирь & коряки & ж & 57 & не анализируется & темный \\
\hline FES-0085 & Сибирь & чукчи & M & 27 & темные & темный \\
\hline FES-0086 & Сибирь & эвены & M & 48 & не анализируется & светлый \\
\hline FES-0087 & Сибирь & чукчи & M & 58 & темные & темный \\
\hline FES-0088 & Сибирь & чукчи & M & 58 & темные & темный \\
\hline FES-0089 & Сибирь & чукчи & M & 56 & не анализируется & темный \\
\hline FES-0090 & Сибирь & коряки & ж & 31 & не анализируется & темный \\
\hline FES-0091 & Сибирь & эвены & M & 35 & темные & темный \\
\hline FES-0092 & Сибирь & чукчи & M & 34 & темные & темный \\
\hline FES-0093 & Сибирь & ительмены & ж & 59 & не анализируется & темный \\
\hline FES-0094 & Сибирь & ительмены & ж & 58 & не анализируется & темный \\
\hline FES-0095 & Сибирь & ительмены & M & 49 & темные & темный \\
\hline FES-0096 & Сибирь & ительмены & ж & 70 & не анализируется & темный \\
\hline FES-0097 & Сибирь & ительмены & M & 38 & темные & темный \\
\hline FES-0098 & Сибирь & ительмены & ж & 60 & не анализируется & темный \\
\hline FES-0099 & Сибирь & ительмены & ж & 60 & не анализируется & темный \\
\hline FES-0100 & Сибирь & ительмены & M & 20 & темные & темный \\
\hline FES-0101 & Сибирь & ительмены & ж & 55 & не анализируется & темный \\
\hline FES-0102 & Сибирь & ительмены & ж & 40 & не анализируется & темный \\
\hline FES-0103 & Сибирь & ительмены & M & 39 & темные & темный \\
\hline FES-0104 & Сибирь & ительмены & ж & 56 & не анализируется & темный \\
\hline
\end{tabular}




\begin{tabular}{|c|c|c|c|c|c|c|}
\hline Образец & Метапопуляция & Этнос & Пол & Возраст на момент сбора & Цвет волос & Цвет глаз \\
\hline FES-0105 & Сибирь & ительмены & ж & 71 & не анализируется & темный \\
\hline FES-0106 & Сибирь & ительмены & M & 59 & не анализируется & темный \\
\hline FES-0107 & Сибирь & ительмены & ж & 47 & не анализируется & темный \\
\hline FES-0108 & Сибирь & ительмены & M & 58 & темные & темный \\
\hline FES-0109 & Европейская часть России & марийцы & M & 64 & не анализируется & темный \\
\hline FES-0110 & Европейская часть России & марийцы & M & 56 & темные & светлый \\
\hline FES-0111 & Европейская часть России & марийцы & M & 59 & не анализируется & темный \\
\hline FES-0112 & Европейская часть России & марийцы & M & 38 & темные & светлый \\
\hline FES-0113 & Европейская часть России & марийцы & M & 49 & промежуточные & светлый \\
\hline FES-0114 & Европейская часть России & марийцы & M & 58 & темные & темный \\
\hline FES-0115 & Европейская часть России & марийцы & M & 50 & темные & светлый \\
\hline FES-0116 & Европейская часть России & марийцы & M & 54 & темные & темный \\
\hline FES-0117 & Европейская часть России & марийцы & M & 46 & темные & смешанный \\
\hline FES-0118 & Европейская часть России & марийцы & M & 45 & темные & светлый \\
\hline FES-0119 & Европейская часть России & марийцы & M & 70 & не анализируется & темный \\
\hline FES-0120 & Европейская часть России & марийцы & M & 66 & темные & смешанный \\
\hline FES-0121 & Европейская часть России & марийцы & M & 66 & не анализируется & светлый \\
\hline FES-0122 & Европейская часть России & марийцы & M & 23 & рыжие & смешанный \\
\hline FES-0123 & Европейская часть России & марийцы & M & 51 & светлые & смешанный \\
\hline FES-0124 & Европейская часть России & марийцы & M & 37 & рыжие & светлый \\
\hline FES-0125 & Европейская часть России & марийцы & $\mathrm{M}$ & 58 & не анализируется & темный \\
\hline FES-0126 & Европейская часть России & марийцы & M & 64 & промежуточные & светлый \\
\hline FES-0127 & Европейская часть России & марийцы & M & 61 & не анализируется & темный \\
\hline FES-0128 & Европейская часть России & марийцы & M & 57 & промежуточные & темный \\
\hline FES-0129 & Европейская часть России & русские & M & 59 & темные & светлый \\
\hline FES-0130 & Европейская часть России & русские & M & 34 & промежуточные & светлый \\
\hline FES-0131 & Европейская часть России & русские & $\mathrm{M}$ & 34 & темные & светлый \\
\hline FES-0132 & Европейская часть России & русские & M & 40 & темные & темный \\
\hline FES-0133 & Европейская часть России & русские & M & 32 & темные & светлый \\
\hline FES-0134 & Европейская часть России & русские & M & 52 & промежуточные & светлый \\
\hline FES-0135 & Европейская часть России & русские & M & 30 & темные & темный \\
\hline FES-0136 & Европейская часть России & русские & M & 41 & темные & светлый \\
\hline FES-0137 & Европейская часть России & карелы & M & 75 & промежуточные & светлый \\
\hline FES-0138 & Европейская часть России & карелы & M & 79 & не анализируется & светлый \\
\hline FES-0139 & Европейская часть России & карелы & $\mathrm{M}$ & 70 & не анализируется & светлый \\
\hline FES-0140 & Европейская часть России & карелы & M & 66 & промежуточные & светлый \\
\hline FES-0141 & Европейская часть России & карелы & ж & 79 & не анализируется & светлый \\
\hline FES-0142 & Европейская часть России & карелы & M & 68 & темные & светлый \\
\hline FES-0143 & Европейская часть России & карелы & M & 59 & не анализируется & светлый \\
\hline FES-0144 & Европейская часть России & карелы & $\mathrm{M}$ & 62 & темные & светлый \\
\hline
\end{tabular}

с рыжим цветом волос. Частота встречаемости этого полиморфизма, по данным ЕхАС, составляет 0,0038 для Европы и 0,0000 (менее 0.0001) для Азии, поэтому вероятность присутствия хотя бы двух альтернативных аллелей в нашей выборке ничтожна. Это позволило нам для целей получения предсказания цвета волос присвоить данному маркеру генотип 0/0 для всех образцов.

Отбор генотипов проводили с помощью программного обеспечения PLINK 1.9 [15]. Полученные генотипы представлены в табл. 2.

C использованием системы HIrisPlex-S с помощью онлайн-инструмента Департамента генетической идентификации Erasmus MC [16] были получены предсказания цвета глаз (светлые, промежуточные или темные) и волос (рыжие, светлые, промежуточные или темные) для всех образцов.

\section{Оценка точности предсказания цвета глаз и волос}

Фенотипы, предсказанные системой HlrisPlex на основе генотипов, сопоставляли с истинными фенотипами, определенными антропологами по фотографиям, и рассчитывали статистические показатели качества предсказания для всех 144 образцов. Полученные нами 
Таблица 2. Генотипы маркеров, входящих в панель HIrisPlex для предсказания цвета глаз и волос

\begin{tabular}{|c|c|c|c|c|c|c|c|c|c|c|c|c|c|c|}
\hline RS & rs11547464 & rs1805005 & rs1805006 & rs1805007 & rs2228479 & rs1110400 & rs28777 & rs 12821256 & rs4959270 & rs12203592 & rs1042602 & rs1800407 & rs2402130 & rs 12913832 \\
\hline $\begin{array}{c}\text { Пред- } \\
\text { сказание } \\
\text { цвета }\end{array}$ & $\begin{array}{l}\text { глаз и } \\
\text { волос }\end{array}$ & $\begin{array}{l}\text { глаз и } \\
\text { волос }\end{array}$ & $\begin{array}{l}\text { глаз и } \\
\text { волос }\end{array}$ & $\begin{array}{l}\text { глаз и } \\
\text { волос }\end{array}$ & $\begin{array}{l}\text { глаз и } \\
\text { волос }\end{array}$ & $\begin{array}{l}\text { глаз и } \\
\text { волос }\end{array}$ & $\begin{array}{l}\text { глаз и } \\
\text { волос }\end{array}$ & $\begin{array}{l}\text { глаз и } \\
\text { волос }\end{array}$ & $\begin{array}{l}\text { глаз и } \\
\text { волос }\end{array}$ & $\begin{array}{l}\text { глаз и } \\
\text { волос }\end{array}$ & $\begin{array}{l}\text { глаз и } \\
\text { волос }\end{array}$ & $\begin{array}{l}\text { глаз и } \\
\text { волос }\end{array}$ & $\begin{array}{l}\text { глаз и } \\
\text { волос }\end{array}$ & $\begin{array}{l}\text { глаз и } \\
\text { волос }\end{array}$ \\
\hline CHROM & 16 & 16 & 16 & 16 & 16 & 16 & 5 & 12 & 6 & 6 & 11 & 15 & 14 & 15 \\
\hline POS & 89986091 & 89985844 & 89985918 & 89986117 & 89985940 & 89986130 & 33958959 & 89328335 & 457748 & 396321 & 88911696 & 28230318 & 92801203 & 28365618 \\
\hline REF & G & c & c & G & G & A & c & A & c & G & c & G & A & A \\
\hline ALT & A & A & A & A & A & G & A & G & A & A & A & A & G & G \\
\hline FES-0001 & $0 / 0$ & $0 / 1$ & $0 / 0$ & $0 / 0$ & $0 / 0$ & $0 / 0$ & $0 / 0$ & $0 / 0$ & $0 / 0$ & $0 / 0$ & $0 / 0$ & $0 / 0$ & $0 / 0$ & $0 / 0$ \\
\hline FES-0002 & $0 / 0$ & $0 / 0$ & $0 / 0$ & $0 / 0$ & $0 / 0$ & $0 / 0$ & $0 / 0$ & $0 / 0$ & $1 / 1$ & $0 / 0$ & $0 / 0$ & $0 / 0$ & $0 / 0$ & $0 / 0$ \\
\hline FES-0003 & $0 / 0$ & $0 / 0$ & $0 / 0$ & $0 / 0$ & $0 / 0$ & $0 / 0$ & $0 / 0$ & $0 / 0$ & $0 / 0$ & $0 / 0$ & $0 / 0$ & $0 / 0$ & $0 / 0$ & $0 / 0$ \\
\hline FES-0004 & $0 / 0$ & $0 / 0$ & $0 / 0$ & $0 / 0$ & $0 / 0$ & $0 / 0$ & $0 / 0$ & $0 / 0$ & $0 / 0$ & $0 / 0$ & $0 / 0$ & $0 / 0$ & $0 / 0$ & $0 / 0$ \\
\hline FES-0005 & $0 / 0$ & $0 / 0$ & $0 / 0$ & $0 / 0$ & $0 / 0$ & $0 / 0$ & $0 / 0$ & $0 / 0$ & $0 / 0$ & $0 / 0$ & $0 / 0$ & $0 / 0$ & $0 / 1$ & $0 / 1$ \\
\hline FES-0006 & $0 / 0$ & $0 / 0$ & $0 / 0$ & $0 / 0$ & $0 / 0$ & $0 / 0$ & $0 / 0$ & $0 / 0$ & $0 / 0$ & $0 / 0$ & $0 / 0$ & $0 / 0$ & $0 / 0$ & $0 / 1$ \\
\hline FES-0007 &. & $0 / 1$ & $0 / 0$ &. & $0 / 1$ & $0 / 0$ & $0 / 0$ & $0 / 0$ & $0 / 0$ & $0 / 0$ & $0 / 0$ & $0 / 0$ & $0 / 0$ & $0 / 0$ \\
\hline FES-0008 & $0 / 0$ & $0 / 0$ & $0 / 0$ & $0 / 0$ & $0 / 0$ & $0 / 0$ & $0 / 0$ & $0 / 0$ & $0 / 0$ & $0 / 0$ & $0 / 0$ & $0 / 0$ & $0 / 0$ & $0 / 0$ \\
\hline FES-0009 & $0 / 0$ & $0 / 0$ & $0 / 0$ & $0 / 0$ & $0 / 0$ & $0 / 0$ & $0 / 0$ & $0 / 0$ & $0 / 0$ & $0 / 0$ & $0 / 0$ & $0 / 0$ & $0 / 0$ & $0 / 0$ \\
\hline FES-0010 & $0 / 0$ & $0 / 0$ & $0 / 0$ & $0 / 0$ & $0 / 0$ & $0 / 0$ & $0 / 0$ & $0 / 0$ & $0 / 0$ & $0 / 0$ & $0 / 0$ & $0 / 0$ & $0 / 0$ & $0 / 0$ \\
\hline FES-0011 & $0 / 0$ & $0 / 0$ & $0 / 0$ & $0 / 0$ & $0 / 0$ & $0 / 0$ & $0 / 0$ & $0 / 0$ & $0 / 1$ & $0 / 0$ & $0 / 0$ & $0 / 0$ & $0 / 0$ & $0 / 0$ \\
\hline FES-0012 & $0 / 0$ & $0 / 0$ & $0 / 0$ & $0 / 0$ & $0 / 1$ & $0 / 0$ & $0 / 0$ & $0 / 0$ & $1 / 1$ & $0 / 0$ & $0 / 0$ & $0 / 0$ & $0 / 0$ & $0 / 0$ \\
\hline FES- 0013 & $0 / 0$ & $0 / 0$ & 0/0 & $0 / 0$ & $0 / 0$ & 0/0 & $0 / 0$ & $0 / 0$ & $0 / 1$ & $0 / 0$ & $0 / 0$ & $0 / 0$ & $0 / 0$ & $0 / 0$ \\
\hline FES-0014 & $0 / 0$ & $0 / 0$ & $0 / 0$ & $0 / 0$ & $0 / 1$ & $0 / 0$ & $0 / 0$ & $0 / 0$ & $0 / 1$ & $0 / 0$ & $0 / 0$ & $0 / 0$ & $0 / 1$ & $0 / 0$ \\
\hline FES-0015 & $0 / 0$ & $0 / 0$ & $0 / 0$ & $0 / 0$ & $0 / 0$ & $0 / 0$ & $0 / 0$ & $0 / 0$ & $1 / 1$ & $0 / 0$ & $0 / 0$ & $0 / 0$ & $0 / 1$ & $0 / 0$ \\
\hline FES-0016 & $0 / 0$ & $0 / 0$ & $0 / 0$ & $0 / 0$ & $0 / 1$ & $0 / 0$ & $0 / 0$ & $0 / 0$ & $0 / 1$ & $0 / 0$ & $0 / 0$ & $0 / 0$ & $0 / 1$ & $0 / 0$ \\
\hline FES-0017 & $0 / 0$ & $0 / 0$ & $0 / 0$ & $0 / 0$ & $0 / 1$ & $0 / 0$ & $0 / 0$ & $0 / 0$ & $0 / 0$ & $0 / 0$ & $0 / 0$ & $0 / 0$ & $0 / 1$ & $0 / 0$ \\
\hline FES-0018 & $0 / 0$ & $0 / 0$ & $0 / 0$ & $0 / 0$ & $0 / 0$ & $0 / 0$ & $0 / 1$ & $0 / 0$ & $0 / 0$ & $0 / 0$ & $1 / 1$ & $0 / 0$ & $0 / 0$ & $0 / 1$ \\
\hline FES-0019 & $0 / 0$ & $0 / 0$ & $0 / 0$ & $0 / 0$ & $0 / 0$ & $0 / 0$ & $0 / 1$ & $0 / 0$ & $0 / 1$ & $0 / 0$ & $0 / 0$ & $0 / 0$ & $0 / 0$ & $0 / 0$ \\
\hline FES-0020 & $0 / 0$ & $0 / 0$ & $0 / 0$ & $0 / 0$ & $0 / 1$ & $0 / 0$ & $0 / 0$ & $0 / 0$ & $1 / 1$ & $0 / 1$ & $0 / 0$ & $0 / 0$ & $0 / 0$ & $0 / 0$ \\
\hline FES-0021 & $0 / 0$ & $0 / 0$ & $0 / 0$ & $0 / 0$ & $0 / 0$ & $0 / 0$ & $0 / 0$ & $0 / 0$ & $0 / 1$ & $0 / 0$ & $0 / 0$ & $0 / 0$ & $0 / 0$ & $0 / 0$ \\
\hline FES-0022 & $0 / 0$ & $0 / 0$ & $0 / 0$ & $0 / 0$ & $0 / 0$ & $0 / 0$ & $0 / 1$ & $0 / 0$ & $0 / 1$ & $0 / 0$ & $0 / 0$ & $0 / 0$ & $0 / 0$ & $0 / 0$ \\
\hline FES-0023 & $0 / 0$ & $0 / 0$ & $0 / 0$ & $0 / 0$ & $0 / 0$ & $0 / 0$ & $1 / 1$ & $0 / 0$ & $1 / 1$ & $0 / 1$ & $0 / 1$ & $0 / 0$ & $0 / 1$ & $0 / 1$ \\
\hline FES-0024 & $0 / 0$ & $0 / 0$ & $0 / 0$ & $0 / 0$ & $0 / 0$ & $0 / 0$ & $1 / 1$ & $0 / 1$ & $0 / 0$ & $0 / 0$ & $0 / 1$ & $0 / 0$ & $0 / 0$ & $1 / 1$ \\
\hline FES-0025 & $0 / 0$ & $0 / 0$ & $0 / 0$ & $0 / 1$ & $0 / 0$ & $0 / 0$ & $1 / 1$ & $0 / 0$ & $0 / 1$ & $0 / 1$ & $0 / 0$ & $0 / 0$ & $0 / 0$ & $0 / 1$ \\
\hline FES-0026 & $0 / 0$ & $0 / 0$ & $0 / 0$ & $0 / 0$ & $0 / 0$ & $0 / 0$ & $1 / 1$ & $0 / 0$ & $0 / 0$ & $0 / 0$ & $0 / 1$ & $0 / 0$ & $0 / 1$ & $1 / 1$ \\
\hline FES-0027 & $0 / 0$ & $0 / 0$ & $0 / 0$ & $0 / 0$ & $0 / 0$ & $0 / 0$ & $0 / 1$ & 0/1 & $0 / 0$ & $0 / 0$ & $0 / 0$ &.$\%$ & $0 / 0$ & $0 / 0$ \\
\hline FES-0028 & $0 / 0$ & $0 / 0$ & $0 / 0$ & $0 / 1$ & $0 / 0$ & $0 / 0$ & $0 / 1$ & $0 / 0$ & $0 / 1$ & $0 / 0$ & $0 / 1$ & $0 / 0$ & $0 / 0$ & $1 / 1$ \\
\hline FES-0029 & $0 / 0$ & $0 / 1$ & $0 / 0$ & 0/1 &. & $0 / 0$ &. & $0 / 0$ & $1 / 1$ & $0 / 0$ & $0 / 0$ & $0 / 0$ & $0 / 0$ & $0 / 1$ \\
\hline FES-0030 & $0 / 0$ & $0 / 0$ & $0 / 0$ & $0 / 1$ & $0 / 0$ & $0 / 0$ & $0 / 1$ & $0 / 0$ & $0 / 0$ & $0 / 0$ & $0 / 0$ & $0 / 0$ & $0 / 0$ & $0 / 1$ \\
\hline FES-0031 & $0 / 0$ & $0 / 0$ & $0 / 0$ & $0 / 0$ & $0 / 0$ & $0 / 0$ & $1 / 1$ & $0 / 0$ & $0 / 0$ & $0 / 0$ & $0 / 0$ & $0 / 1$ & $0 / 0$ & $0 / 1$ \\
\hline FES-0032 & $0 / 0$ & $0 / 0$ & $0 / 0$ & $0 / 0$ & $0 / 1$ & $0 / 0$ & $1 / 1$ & $0 / 0$ & $0 / 1$ & $1 / 1$ & $0 / 1$ & $0 / 0$ & $0 / 1$ & 0/1 \\
\hline FES- 0033 & $0 / 0$ & $0 / 0$ & $0 / 0$ & $0 / 0$ & $0 / 1$ & $0 / 0$ & $1 / 1$ & $0 / 0$ & $0 / 1$ & $0 / 0$ & $0 / 1$ & $0 / 0$ & $0 / 1$ & $0 / 1$ \\
\hline FES-0034 & $0 / 0$ & $0 / 0$ & $0 / 0$ & $0 / 0$ & $0 / 1$ & $0 / 0$ & $1 / 1$ & $0 / 0$ & $0 / 1$ & $0 / 0$ & $0 / 0$ & $0 / 0$ & $0 / 0$ & $0 / 1$ \\
\hline FES-0035 & $0 / 0$ & $0 / 0$ & o/0 & $0 / 0$ & $0 / 0$ & 0/0 & $1 / 1$ & $0 / 0$ & $1 / 1$ & $0 / 0$ & $0 / 1$ & $0 / 0$ & $0 / 0$ & 0/1 \\
\hline FES-0036 & $0 / 0$ & $0 / 0$ & $0 / 0$ & $0 / 0$ & $0 / 1$ & 0/0 & $1 / 1$ & $0 / 0$ & $0 / 1$ & $0 / 0$ & $0 / 1$ & $0 / 0$ & $0 / 0$ & 0/1 \\
\hline FES-0037 & $0 / 0$ & $0 / 0$ & $0 / 0$ & $0 / 0$ & $0 / 0$ & $0 / 0$ & $1 / 1$ & $0 / 0$ & $1 / 1$ & $0 / 1$ & $0 / 0$ & $0 / 0$ & $0 / 0$ & $0 / 1$ \\
\hline FES-0038 & $0 / 0$ & $0 / 0$ & $0 / 0$ & $0 / 0$ & $0 / 0$ & $0 / 0$ & $1 / 1$ & $0 / 0$ & $0 / 0$ & $0 / 0$ & $0 / 0$ & $0 / 1$ & $0 / 0$ & $0 / 1$ \\
\hline FES-0039 & $0 / 0$ & $0 / 0$ & 0/0 & $0 / 0$ & $0 / 0$ & $0 / 0$ & $1 / 1$ & $0 / 1$ & $0 / 1$ & $0 / 0$ & $0 / 1$ & $0 / 0$ & $0 / 1$ & $1 / 1$ \\
\hline FES-0040 & $0 / 0$ & $0 / 0$ & o/0 & $0 / 0$ & $0 / 0$ & 0/0 & $1 / 1$ & $0 / 0$ & $0 / 0$ & $0 / 1$ & 0/0 & $0 / 0$ & $0 / 0$ & $1 / 1$ \\
\hline FES-0041 & $0 / 0$ & $0 / 0$ & $0 / 0$ & $0 / 0$ & $0 / 0$ & $0 / 0$ & $1 / 1$ & $0 / 0$ & $0 / 1$ & $0 / 1$ & $0 / 0$ & $0 / 0$ & $0 / 1$ & $1 / 1$ \\
\hline FES-0042 & $0 / 0$ & $0 / 0$ & $0 / 0$ & $0 / 0$ & $0 / 0$ & $0 / 0$ &. & $0 / 0$ & $1 / 1$ & $0 / 0$ & $0 / 1$ & $0 / 0$ & $0 / 0$ & $0 / 1$ \\
\hline FES-0043 & $0 / 0$ & $0 / 0$ & $0 / 0$ & $0 / 0$ & $0 / 0$ & $0 / 0$ & $1 / 1$ & $0 / 0$ & $0 / 0$ & $0 / 0$ & $0 / 0$ & $0 / 1$ & $0 / 1$ & $0 / 1$ \\
\hline FES-0044 & $0 / 0$ & 0/0 & $0 / 0$ & o/0 & $0 / 0$ & 0/0 & $1 / 1$ & $0 / 0$ & $0 / 0$ & $0 / 0$ & $0 / 1$ & $0 / 0$ & $0 / 1$ & $1 / 1$ \\
\hline FES-0045 & $0 / 0$ & $0 / 0$ & $0 / 0$ & $0 / 0$ & $0 / 0$ & $0 / 0$ & $1 / 1$ & $0 / 0$ & $0 / 0$ & $0 / 0$ & $0 / 1$ & $0 / 0$ & $0 / 1$ & $0 / 0$ \\
\hline FES-0046 & $0 / 0$ & $0 / 0$ & $0 / 0$ & $0 / 0$ & $0 / 1$ & $0 / 0$ & $0 / 1$ & $0 / 1$ & $1 / 1$ & $0 / 0$ & $0 / 1$ & $0 / 0$ & $0 / 0$ & $0 / 0$ \\
\hline FES- 0047 & $0 / 0$ & $0 / 1$ & 0/0 & $0 / 0$ & $0 / 0$ & $0 / 0$ & $1 / 1$ & $0 / 0$ & $0 / 1$ & $0 / 0$ & 0/0 & $0 / 0$ & $0 / 1$ & $0 / 1$ \\
\hline FES-0048 & $0 / 0$ & $0 / 0$ & $0 / 0$ & $0 / 0$ & $0 / 0$ & $0 / 0$ & $1 / 1$ & $0 / 0$ & $0 / 1$ & $0 / 1$ & $0 / 0$ & $0 / 1$ & 0/1 & $0 / 1$ \\
\hline FES-0049 & $0 / 0$ & $0 / 0$ & $0 / 0$ & $0 / 0$ & $0 / 0$ & $0 / 0$ &. & $0 / 0$ & $0 / 1$ & $0 / 0$ & $0 / 0$ & $0 / 0$ & $0 / 0$ & $0 / 0$ \\
\hline FES-0050 & $0 / 0$ & $0 / 0$ & $0 / 0$ & $0 / 0$ & $0 / 0$ & $0 / 0$ & $1 / 1$ & $0 / 0$ & $0 / 0$ & $0 / 0$ & $0 / 1$ & $0 / 0$ & $0 / 1$ & $0 / 0$ \\
\hline FES-0051 & $0 / 0$ & $0 / 0$ & $0 / 0$ & $0 / 0$ & $0 / 0$ & $0 / 0$ & $1 / 1$ & $0 / 0$ & $0 / 1$ & $0 / 0$ & $0 / 0$ & 0/1 & $0 / 0$ & 0/1 \\
\hline FES-0052 & $0 / 0$ & 0/0 & $0 / 0$ & $0 / 0$ & $0 / 0$ & o/0 & 0/1 &.$\%$ & 0/0 & o/0 & $0 / 0$ & o/0 & $0 / 0$ & o/0 \\
\hline
\end{tabular}


Продолжение таблицы 2

\begin{tabular}{|c|c|c|c|c|c|c|c|c|c|c|c|c|c|c|}
\hline rs2378249 & rs12896399 & rs 1393350 & rs683 & rs3114908 & rs1800414 & rs 10756819 & rs17128291 & rs1129038 & rs1667394 & rs1126809 & rs1470608 & rs1426654 & rs6059655 & rs8051733 \\
\hline $\begin{array}{l}\text { глаз и } \\
\text { волос }\end{array}$ & $\begin{array}{l}\text { глаз и } \\
\text { волос }\end{array}$ & $\begin{array}{l}\text { глаз и } \\
\text { волос }\end{array}$ & $\begin{array}{l}\text { глаз и } \\
\text { волос }\end{array}$ & $\begin{array}{l}\text { глаз и } \\
\text { волос }\end{array}$ & кожи & кожи & кожи & кожи & кожи & кожи & кожи & кожи & кожи & кожи \\
\hline 20 & 14 & 11 & 9 & 16 & 15 & 9 & 14 & 15 & 15 & 11 & 15 & 15 & 20 & 16 \\
\hline 33218090 & 92773663 & 89011046 & 12709305 & 89383725 & 28197037 & 16858084 & 92882826 & 28356859 & 28530182 & 89017961 & 28288121 & 48426484 & 32665748 & 90024206 \\
\hline A & c & G & c & G & A & A & A & G & A & G & A & A & G & A \\
\hline G & A & A & A & A & G & G & G & A & G & A & C & G & A & G \\
\hline $0 / 0$ & $0 / 0$ & 0/0 & $0 / 0$ & $1 / 1$ & $0 / 0$ & $1 / 1$ & $1 / 1$ & o/0 & $1 / 1$ & $0 / 0$ & $0 / 0$ & $1 / 1$ & $0 / 0$ & $0 / 0$ \\
\hline $1 / 1$ & $0 / 0$ & $0 / 0$ & $0 / 0$ & $0 / 0$ & $0 / 1$ & $0 / 0$ & $0 / 0$ & $0 / 0$ & $0 / 1$ & $0 / 0$ & $0 / 0$ & $1 / 1$ & $0 / 0$ & $0 / 0$ \\
\hline $0 / 0$ & $0 / 0$ & $0 / 0$ & $0 / 0$ & $0 / 0$ & $0 / 0$ & $0 / 1$ & $0 / 0$ & $0 / 0$ & $0 / 1$ & $0 / 0$ & $0 / 1$ & $1 / 1$ & $0 / 0$ & $0 / 0$ \\
\hline $0 / 0$ & $0 / 1$ & $0 / 0$ & $0 / 0$ & $0 / 0$ & $0 / 0$ & $0 / 0$ & $0 / 0$ & $0 / 0$ & $0 / 1$ & $0 / 0$ & $0 / 0$ & $0 / 1$ & $0 / 0$ & $0 / 0$ \\
\hline $0 / 0$ & $0 / 0$ & $0 / 0$ & $0 / 0$ & $0 / 1$ & $0 / 0$ & $0 / 0$ & $0 / 1$ & $0 / 1$ & $0 / 0$ & $0 / 0$ & $0 / 1$ & $0 / 1$ & $0 / 0$ & $0 / 0$ \\
\hline $0 / 0$ & $0 / 1$ & $0 / 0$ & $0 / 0$ & $0 / 0$ & $0 / 0$ & $0 / 1$ & $0 / 0$ & $0 / 1$ & $0 / 0$ & $0 / 0$ & $0 / 1$ & $0 / 1$ & $0 / 0$ & $0 / 0$ \\
\hline $0 / 0$ & $0 / 0$ & $0 / 0$ & $0 / 0$ &. &. & $0 / 1$ & 0/0 &. & $0 / 1$ &. & $0 / 0$ & $1 / 1$ & $0 / 0$ & $0 / 1$ \\
\hline $0 / 0$ & $0 / 1$ & $0 / 0$ & $0 / 0$ & $0 / 0$ & $0 / 0$ & $0 / 1$ & $0 / 0$ & $0 / 0$ & $0 / 1$ &.$\%$ & $0 / 0$ & $1 / 1$ & $0 / 0$ & $0 / 0$ \\
\hline $0 / 0$ & $0 / 1$ & $0 / 0$ & $0 / 0$ & $0 / 0$ & $0 / 0$ & $0 / 0$ & $0 / 0$ & $0 / 0$ & $1 / 1$ &. & $0 / 0$ & $1 / 1$ & $0 / 0$ & $0 / 0$ \\
\hline $0 / 1$ & $0 / 1$ & $0 / 0$ & $0 / 0$ & $0 / 0$ & $0 / 0$ & $0 / 1$ & $0 / 0$ & $0 / 0$ & $0 / 1$ &. & $0 / 0$ & $1 / 1$ & $0 / 0$ & $0 / 0$ \\
\hline $0 / 1$ & $0 / 1$ & $0 / 0$ & $0 / 0$ & $0 / 0$ & $0 / 0$ & $0 / 0$ & $0 / 0$ & $0 / 0$ & $0 / 1$ &. & $0 / 0$ & $1 / 1$ & $0 / 0$ & $1 / 1$ \\
\hline $0 / 0$ & $0 / 0$ & $0 / 0$ & $0 / 0$ & $0 / 1$ & $0 / 0$ & $0 / 0$ & $0 / 0$ & $0 / 0$ & $1 / 1$ &. & $0 / 0$ & $1 / 1$ & $0 / 0$ & $0 / 1$ \\
\hline $0 / 1$ & $0 / 1$ & $0 / 0$ & $0 / 1$ & $0 / 1$ & $0 / 0$ & $0 / 0$ & 0/0 & 0/0 & $0 / 1$ & $0 / 0$ & $0 / 0$ & $1 / 1$ & $0 / 0$ & $0 / 0$ \\
\hline $0 / 0$ & $0 / 1$ & $0 / 0$ & $0 / 0$ & $0 / 1$ & $0 / 0$ & $0 / 0$ & $0 / 0$ & $0 / 0$ & $0 / 1$ & $0 / 0$ & $0 / 0$ & $1 / 1$ & $0 / 0$ & $0 / 1$ \\
\hline $0 / 1$ & $0 / 0$ & 0/0 & 0/0 & $0 / 1$ & o/0 & $0 / 1$ & $0 / 1$ & 0/0 & $0 / 1$ & 0/0 & $0 / 0$ & $1 / 1$ & $0 / 0$ & $0 / 0$ \\
\hline $0 / 1$ & $0 / 1$ & 0/0 & 0/0 & 0/1 & $0 / 0$ & $0 / 0$ & 0/0 & 0/0 & 0/1 & 0/0 & $0 / 1$ & $1 / 1$ & $0 / 0$ & $0 / 1$ \\
\hline $0 / 1$ & 0/0 & o/0 & o/0 & 0/0 & $0 / 0$ & $1 / 1$ & o/0 & o/0 & o/0 & o/0 & $0 / 0$ & $1 / 1$ & 0/0 & $0 / 1$ \\
\hline o/0 & $0 / 0$ & 0/0 & 0/1 & $1 / 1$ & 0/0 & $0 / 1$ & 0/0 & $0 / 1$ & $0 / 1$ &. & $0 / 1$ & $0 / 0$ & $0 / 0$ & $0 / 0$ \\
\hline $1 / 1$ & $0 / 0$ & $0 / 1$ & $0 / 1$ & $0 / 1$ & $1 / 1$ & $0 / 0$ & $0 / 0$ & $0 / 0$ & $1 / 1$ &. & $0 / 0$ & $0 / 1$ & $0 / 0$ & $0 / 0$ \\
\hline $0 / 1$ & $0 / 0$ & 0/0 & 0/0 & $0 / 1$ & 0/0 & $0 / 1$ & 0/0 & 0/0 & 0/0 &. & $0 / 1$ & $0 / 0$ & $0 / 0$ & $1 / 1$ \\
\hline $0 / 1$ & $0 / 0$ & $0 / 1$ & $0 / 0$ & $0 / 0$ & $0 / 0$ & $0 / 1$ & $0 / 0$ & $0 / 0$ & $0 / 1$ &. & $0 / 0$ & $0 / 1$ & $0 / 0$ & $0 / 0$ \\
\hline 0/1 & $0 / 0$ & 0/0 & o/0 & $1 / 1$ & o/0 & 0/1 & 0/0 & o/0 & 0/1 &. & $0 / 0$ & $0 / 1$ & $0 / 0$ & $0 / 0$ \\
\hline $0 / 1$ & $0 / 0$ & 0/0 & $1 / 1$ & $0 / 1$ & $0 / 0$ & $1 / 1$ & 0/0 & $0 / 1$ & $0 / 1$ &. & $1 / 1$ & $0 / 0$ & $0 / 0$ & $0 / 0$ \\
\hline $0 / 0$ & $0 / 0$ & 0/1 & $1 / 1$ & 0/1 & o/0 & $1 / 1$ & o/0 & $1 / 1$ & o/0 &. & $1 / 1$ & $0 / 0$ & $0 / 0$ & $0 / 1$ \\
\hline $0 / 0$ & $0 / 0$ & 0/0 & $0 / 1$ & $1 / 1$ & 0/0 & $0 / 1$ & 0/0 & $0 / 1$ & 0/0 &. & $0 / 1$ & $0 / 1$ & $0 / 0$ & $1 / 1$ \\
\hline o/0 & $0 / 0$ & $0 / 1$ & 0/1 & $0 / 0$ & $0 / 0$ & 0/1 & $0 / 1$ & $1 / 1$ & o/0 &.$\%$ & $0 / 1$ & $0 / 0$ & $0 / 0$ & $0 / 0$ \\
\hline $0 / 0$ & $0 / 0$ & $0 / 0$ & $0 / 1$ & $0 / 0$ & $0 / 0$ & $0 / 0$ & $1 / 1$ & $0 / 0$ & $0 / 1$ &. & $0 / 1$ & $0 / 0$ & $0 / 0$ & $0 / 0$ \\
\hline $0 / 1$ & $1 / 1$ & 0/0 & 0/1 & $0 / 1$ & 0/0 & $0 / 1$ & $0 / 1$ & $1 / 1$ & 0/0 &. & $1 / 1$ & 0/0 & 0/1 & $0 / 1$ \\
\hline $0 / 0$ & $0 / 1$ & $0 / 1$ & $1 / 1$ & $0 / 0$ & $0 / 0$ & $0 / 0$ & 0/0 & $0 / 1$ & $0 / 0$ &. &. & $0 / 0$ & $0 / 0$ & $0 / 1$ \\
\hline $0 / 0$ & $0 / 0$ & $0 / 0$ & $0 / 1$ & $0 / 1$ & $0 / 0$ & $1 / 1$ & $0 / 0$ & $0 / 1$ & $0 / 0$ &. & $0 / 1$ & $0 / 1$ & $0 / 0$ & $0 / 1$ \\
\hline $0 / 0$ & $0 / 0$ & $0 / 0$ & $1 / 1$ & $0 / 0$ & $0 / 0$ & $0 / 0$ & $0 / 0$ & $0 / 1$ & $0 / 1$ &. & $1 / 1$ & $0 / 0$ & $0 / 0$ & $0 / 0$ \\
\hline $0 / 0$ & $0 / 0$ & $0 / 0$ & $1 / 1$ & $0 / 1$ & $0 / 0$ & $0 / 1$ & $0 / 1$ & $0 / 1$ & $0 / 0$ & $0 / 0$ & $0 / 1$ & $0 / 0$ & $0 / 0$ & $0 / 1$ \\
\hline $0 / 0$ & $0 / 0$ & o/0 & $1 / 1$ & $0 / 1$ & $0 / 0$ & $1 / 1$ & 0/0 & $0 / 1$ & $0 / 1$ & o/0 & $0 / 1$ & $0 / 0$ & $0 / 0$ & $0 / 1$ \\
\hline $0 / 1$ & $0 / 1$ & $0 / 0$ & $0 / 1$ & $1 / 1$ & $0 / 0$ & $0 / 1$ & o/0 & $0 / 1$ & $0 / 1$ & o/0 & $0 / 1$ & 0/0 & $0 / 0$ & $0 / 1$ \\
\hline $0 / 1$ & $0 / 0$ & $0 / 1$ & $1 / 1$ & $0 / 1$ & $0 / 0$ & $0 / 0$ & $0 / 0$ & $0 / 1$ & $0 / 1$ & $0 / 1$ & $0 / 1$ & $0 / 0$ & $0 / 0$ & $0 / 0$ \\
\hline $0 / 1$ & $0 / 1$ & 0/0 & $0 / 1$ & $0 / 1$ & $0 / 0$ & $0 / 0$ & 0/0 & $0 / 1$ & $0 / 1$ & o/0 & 0/1 & $0 / 0$ & $0 / 0$ & $0 / 1$ \\
\hline $0 / 0$ & $0 / 1$ & 0/0 & $0 / 1$ & $1 / 1$ & o/0 & $0 / 1$ & 0/0 & $0 / 1$ & $0 / 1$ & $0 / 0$ & $0 / 1$ & 0/0 & $0 / 0$ & $0 / 0$ \\
\hline $0 / 0$ & $0 / 1$ & o/0 & $0 / 1$ & $0 / 0$ & o/0 & $1 / 1$ & $0 / 1$ & $0 / 1$ & $0 / 1$ & $0 / 0$ & $1 / 1$ & $0 / 0$ & $0 / 0$ & $0 / 0$ \\
\hline $1 / 1$ & $0 / 1$ & $0 / 0$ & $0 / 1$ & $0 / 0$ & $0 / 0$ & $0 / 0$ & $0 / 0$ & $1 / 1$ & $0 / 0$ & $0 / 0$ & $1 / 1$ & $0 / 0$ & $0 / 0$ & $0 / 0$ \\
\hline $0 / 0$ & $0 / 1$ & $0 / 1$ & $0 / 1$ & $0 / 1$ & $0 / 0$ & $0 / 1$ & 0/0 & $1 / 1$ & $0 / 0$ & $0 / 1$ & $1 / 1$ & $0 / 0$ & $0 / 0$ & $0 / 0$ \\
\hline $0 / 0$ & $0 / 0$ & o/0 & $1 / 1$ & $0 / 0$ & o/0 & o/0 & o/0 & $1 / 1$ & o/0 & $0 / 0$ & $1 / 1$ & $0 / 0$ & $0 / 0$ & $0 / 0$ \\
\hline $0 / 1$ & $0 / 0$ & o/0 & o/0 & 0/1 & o/0 & 0/1 & o/0 & 0/1 & 0/1 & o/0 & $1 / 1$ & 0/0 & $0 / 0$ & $0 / 1$ \\
\hline $0 / 1$ & $0 / 0$ & $0 / 1$ & $1 / 1$ & 0/0 & $0 / 0$ & $1 / 1$ & 0/0 & 0/1 & 0/1 & 0/0 & $1 / 1$ & $0 / 0$ & $0 / 0$ & $0 / 1$ \\
\hline $0 / 0$ & $0 / 0$ & $0 / 1$ & 0/1 & $0 / 0$ & o/0 & $0 / 1$ & 0/0 &. & o/0 & o/0 & $0 / 1$ & 0/0 & $0 / 0$ & $0 / 0$ \\
\hline $0 / 0$ & $0 / 0$ & $0 / 0$ & $0 / 1$ & $0 / 0$ & $0 / 0$ & $1 / 1$ & $0 / 0$ & $0 / 0$ & $1 / 1$ & $0 / 0$ & $0 / 0$ & $0 / 0$ & $0 / 0$ & $0 / 0$ \\
\hline $0 / 0$ & $0 / 0$ & 0/0 & $1 / 1$ & 0/0 & o/0 & o/0 & o/0 & 0/0 & 0/0 & o/0 & $0 / 1$ & $0 / 0$ & $0 / 0$ & $1 / 1$ \\
\hline o/0 & $0 / 0$ & $0 / 1$ & 0/1 & 0/1 & o/0 & $0 / 1$ & o/0 & $0 / 1$ & 0/1 & o/0 & $0 / 1$ & $0 / 0$ & $0 / 0$ & $0 / 0$ \\
\hline $0 / 0$ & $0 / 0$ & $0 / 0$ & $0 / 1$ & $0 / 0$ & $0 / 0$ & $0 / 1$ & 0/0 & $0 / 1$ & $0 / 1$ & $0 / 0$ & $1 / 1$ & $0 / 0$ & $0 / 0$ & $0 / 0$ \\
\hline $0 / 1$ & $0 / 0$ & 0/0 & $0 / 0$ & $0 / 0$ & $0 / 0$ & $0 / 0$ & o/0 &. & o/0 & o/0 & $1 / 1$ & $0 / 0$ & $0 / 0$ & $0 / 0$ \\
\hline $0 / 0$ & $0 / 0$ & 0/0 & 0/1 & 0/0 & $0 / 0$ & $0 / 1$ & 0/0 & 0/0 & 0/0 & 0/0 & $1 / 1$ & $0 / 0$ & $0 / 0$ & $0 / 1$ \\
\hline $0 / 0$ & $0 / 1$ & $0 / 1$ & o/0 & $0 / 1$ & o/0 & $0 / 0$ & o/0 & $0 / 1$ & 0/0 & o/0 & $1 / 1$ & $0 / 0$ & $0 / 0$ & $0 / 0$ \\
\hline $1 / 1$ & $1 / 1$ & o/0 & o/0 & o/0 & o/0 & $0 / 1$ & 0/0 & 0/0 & $1 / 1$ & o/0 & $0 / 0$ & $1 / 1$ & $0 / 0$ & $0 / 0$ \\
\hline
\end{tabular}


Продолжение таблицы 2

\begin{tabular}{|c|c|c|c|c|c|c|c|c|c|c|c|c|c|c|}
\hline RS & rs 11547464 & rs1805005 & rs1805006 & rs 1805007 & rs2228479 & rs1110400 & rs28777 & rs12821256 & rs4959270 & rs12203592 & rs1042602 & rs1800407 & rs2402130 & rs12913832 \\
\hline $\begin{array}{l}\text { Пред- } \\
\text { сказание } \\
\text { цвета }\end{array}$ & $\begin{array}{l}\text { глаз и } \\
\text { волос }\end{array}$ & $\begin{array}{l}\text { глаз и } \\
\text { волос }\end{array}$ & $\begin{array}{l}\text { глаз и } \\
\text { волос }\end{array}$ & $\begin{array}{l}\text { глаз и } \\
\text { волос }\end{array}$ & $\begin{array}{l}\text { глаз и } \\
\text { волос }\end{array}$ & $\begin{array}{l}\text { глаз и } \\
\text { волос }\end{array}$ & $\begin{array}{l}\text { глаз и } \\
\text { волос }\end{array}$ & $\begin{array}{l}\text { глаз и } \\
\text { волос }\end{array}$ & $\begin{array}{l}\text { глаз и } \\
\text { волос }\end{array}$ & $\begin{array}{l}\text { глаз и } \\
\text { волос }\end{array}$ & $\begin{array}{l}\text { глаз и } \\
\text { волос }\end{array}$ & $\begin{array}{l}\text { глаз и } \\
\text { волос }\end{array}$ & $\begin{array}{l}\text { глаз и } \\
\text { волос }\end{array}$ & $\begin{array}{l}\text { глаз и } \\
\text { волос }\end{array}$ \\
\hline CHROM & 16 & 16 & 16 & 16 & 16 & 16 & 5 & 12 & 6 & 6 & 11 & 15 & 14 & 15 \\
\hline POS & 89986091 & 89985844 & 89985918 & 89986117 & 89985940 & 89986130 & 33958959 & 89328335 & 457748 & 396321 & 88911696 & 28230318 & 92801203 & 28365618 \\
\hline REF & G & c & c & G & $\mathrm{G}$ & $A$ & c & A & c & G & c & G & A & A \\
\hline ALT & A & A & A & A & A & $\mathrm{G}$ & A & G & $A$ & A & A & A & G & $\mathrm{G}$ \\
\hline FES-0053 & $0 / 0$ & $0 / 0$ & $0 / 0$ & $0 / 0$ & $0 / 0$ & $0 / 0$ & $0 / 1$ &. & $0 / 0$ & $0 / 0$ & $0 / 0$ & $0 / 0$ & $0 / 1$ & $0 / 0$ \\
\hline FES-0054 & $0 / 0$ & $0 / 0$ & $0 / 0$ & $0 / 0$ & $0 / 1$ & $0 / 0$ & $0 / 0$ &. & $0 / 0$ & $0 / 0$ & $0 / 0$ & $0 / 0$ & $0 / 0$ & $0 / 0$ \\
\hline FES-0055 & $0 / 0$ & $0 / 0$ & $0 / 0$ & $0 / 0$ & $0 / 1$ & $0 / 0$ & $0 / 1$ &. & $0 / 1$ & $0 / 1$ & $0 / 0$ & $0 / 0$ & $0 / 1$ & $0 / 0$ \\
\hline FES-0056 & $0 / 0$ & 0/0 & $0 / 0$ & $0 / 0$ & $0 / 0$ & $0 / 0$ & $0 / 0$ &. & $0 / 1$ & $0 / 0$ & $0 / 0$ & $0 / 0$ & $0 / 0$ & $0 / 0$ \\
\hline FES-0057 & $0 / 0$ & $0 / 0$ & $0 / 0$ & $0 / 0$ & $0 / 0$ & $0 / 0$ & $0 / 0$ &. & $0 / 1$ & $0 / 0$ & $0 / 0$ & $0 / 0$ & $0 / 0$ & $0 / 0$ \\
\hline FES-0058 & $0 / 0$ & $0 / 0$ & $0 / 0$ & $0 / 0$ & $0 / 0$ & $0 / 0$ & $0 / 1$ &. & $0 / 0$ & $0 / 0$ & $0 / 0$ & $0 / 0$ & $0 / 1$ & $0 / 0$ \\
\hline FES-0059 & $0 / 0$ & $0 / 0$ & $0 / 0$ & $0 / 0$ & $0 / 1$ & $0 / 0$ & $0 / 0$ &. & $1 / 1$ & $0 / 0$ & $0 / 0$ & $0 / 0$ & $0 / 0$ & $0 / 0$ \\
\hline FES-0060 & $0 / 0$ & $0 / 0$ & $0 / 0$ & $0 / 0$ & $0 / 0$ & $0 / 0$ & $0 / 0$ & $\%$ & $0 / 0$ & $0 / 0$ & $0 / 0$ & $0 / 0$ & $0 / 0$ & $0 / 0$ \\
\hline FES-0061 & $0 / 0$ & $0 / 0$ & $0 / 0$ & $0 / 0$ & $0 / 0$ & $0 / 0$ & $0 / 0$ &. & $0 / 0$ & $0 / 0$ & $0 / 0$ & $0 / 0$ & $0 / 0$ & $0 / 0$ \\
\hline FES-0062 & $0 / 0$ & $0 / 0$ & $0 / 0$ & $0 / 0$ & $0 / 1$ & $0 / 0$ & $0 / 0$ &. & $0 / 1$ & $0 / 0$ & $0 / 0$ & $0 / 0$ & $0 / 0$ & $0 / 0$ \\
\hline FES-0063 & $0 / 0$ & $0 / 0$ & $0 / 0$ & $0 / 0$ & $0 / 1$ & $0 / 0$ & $0 / 0$ &. & $0 / 0$ & $0 / 0$ & $0 / 0$ & $0 / 0$ & $0 / 0$ & $0 / 0$ \\
\hline FES-0064 & $0 / 0$ & $0 / 0$ & $0 / 0$ & $0 / 0$ & $0 / 1$ & $0 / 0$ & $0 / 0$ &. & $0 / 0$ & $0 / 0$ & $0 / 0$ & $0 / 0$ & $0 / 0$ & $0 / 0$ \\
\hline FES-0065 & $0 / 0$ & $0 / 0$ & $0 / 0$ & $0 / 0$ & $0 / 1$ & $0 / 0$ & $0 / 1$ &. & $0 / 0$ & $0 / 0$ & $0 / 0$ & $0 / 0$ & $0 / 0$ & $0 / 1$ \\
\hline FES-0066 & $0 / 0$ & $0 / 0$ & $0 / 0$ & $0 / 0$ & $0 / 0$ & $0 / 0$ & $1 / 1$ &. & $1 / 1$ & $0 / 0$ & $0 / 0$ & $0 / 0$ & $0 / 0$ & $0 / 0$ \\
\hline FES-0067 & $0 / 0$ & $0 / 0$ & $0 / 0$ & $0 / 0$ & $0 / 1$ & $0 / 0$ & $0 / 1$ & $\%$ & $0 / 0$ & $0 / 0$ & $0 / 0$ & $0 / 0$ & $0 / 0$ & $0 / 0$ \\
\hline FES-0068 & $0 / 0$ & $0 / 0$ & $0 / 0$ & $0 / 0$ & $0 / 0$ & $0 / 0$ & $1 / 1$ & $\%$ & $0 / 0$ & $0 / 0$ & $0 / 0$ & $0 / 0$ & $0 / 0$ & $0 / 0$ \\
\hline FES-0069 & $0 / 0$ & $0 / 0$ & $0 / 0$ & $0 / 0$ & $0 / 0$ & $0 / 0$ & $0 / 1$ &. & $1 / 1$ & $0 / 0$ & $0 / 1$ & $0 / 0$ & $0 / 0$ & $1 / 1$ \\
\hline FES-0070 & $0 / 0$ & $0 / 0$ & $0 / 0$ & $0 / 0$ & $0 / 1$ & $0 / 0$ & $0 / 0$ &. & $0 / 1$ & $0 / 0$ & $0 / 0$ & $0 / 0$ & $0 / 0$ & $0 / 1$ \\
\hline FES-0071 & $0 / 0$ & $0 / 0$ & $0 / 0$ & $0 / 0$ & $0 / 1$ & $0 / 0$ & $1 / 1$ &. & $0 / 1$ & $0 / 0$ & $0 / 0$ & $0 / 0$ & $0 / 1$ & $0 / 1$ \\
\hline FES-0072 & $0 / 0$ & $0 / 0$ & $0 / 0$ & $0 / 0$ & $0 / 0$ & $0 / 0$ & $1 / 1$ &. & $0 / 1$ & $0 / 0$ & $0 / 0$ & $0 / 0$ & $0 / 0$ & $0 / 0$ \\
\hline FES-0073 & $0 / 0$ & $0 / 0$ & $0 / 0$ & $0 / 0$ & $0 / 0$ & $0 / 0$ & $0 / 1$ &. & $0 / 1$ & $0 / 0$ & $0 / 0$ & $0 / 0$ & $0 / 1$ & $0 / 1$ \\
\hline FES-0074 & $0 / 0$ & $0 / 0$ & $0 / 0$ & $0 / 0$ & $0 / 0$ & $0 / 0$ & $1 / 1$ &. & $1 / 1$ & $0 / 0$ & $0 / 0$ & $0 / 0$ & $0 / 0$ & $0 / 1$ \\
\hline FES-0075 & $0 / 0$ & $0 / 0$ & $0 / 0$ & $0 / 0$ & $0 / 0$ & $0 / 0$ & $0 / 0$ & $\%$ & $0 / 0$ & $0 / 0$ & $0 / 0$ & $0 / 0$ & $0 / 0$ & $0 / 0$ \\
\hline FES-0076 & $0 / 0$ & $0 / 0$ & $0 / 0$ & $0 / 0$ & $0 / 1$ & $0 / 0$ & $0 / 0$ &. & $0 / 0$ & $0 / 0$ & $0 / 0$ & $0 / 0$ & $0 / 0$ & $0 / 0$ \\
\hline FES-0077 & $0 / 0$ & $0 / 0$ & $0 / 0$ & $0 / 0$ & $0 / 0$ & $0 / 0$ & $0 / 0$ & $\%$ & $0 / 1$ & $0 / 0$ & $0 / 0$ & $0 / 0$ & $0 / 0$ & $0 / 0$ \\
\hline FES-0078 & $0 / 0$ & $0 / 0$ & $0 / 0$ & $0 / 0$ & $0 / 0$ & $0 / 0$ & $0 / 0$ &. & $0 / 0$ & $0 / 0$ & $0 / 0$ & $0 / 0$ & $0 / 0$ & $0 / 0$ \\
\hline FES-0079 & $0 / 0$ & $0 / 0$ & $0 / 0$ & $0 / 0$ & $0 / 0$ & $0 / 0$ & $0 / 0$ &. & $0 / 0$ & $0 / 0$ & $0 / 0$ & $0 / 0$ & $0 / 1$ & $0 / 0$ \\
\hline FES-0080 & $0 / 0$ &. & $0 / 0$ & $0 / 0$ & $0 / 0$ & $0 / 0$ & $0 / 0$ & $\%$ & $0 / 1$ & $0 / 0$ & $0 / 0$ & $0 / 0$ & $0 / 0$ & $0 / 0$ \\
\hline FES-0081 & $0 / 0$ & $0 / 0$ & $0 / 0$ & $0 / 0$ & $0 / 0$ & $0 / 0$ & $0 / 0$ & $\%$ & $0 / 0$ & $0 / 0$ & $0 / 0$ & $0 / 0$ & $0 / 0$ & $0 / 0$ \\
\hline FES-0082 & $0 / 0$ & $0 / 0$ & $0 / 0$ & $0 / 0$ & $0 / 0$ & 0/0 & $0 / 0$ & $\%$ & $0 / 1$ & $0 / 0$ & $0 / 0$ & $0 / 0$ & $0 / 0$ & $0 / 0$ \\
\hline FES-0083 & $0 / 0$ & $0 / 0$ & $0 / 0$ & $0 / 0$ & $1 / 1$ & $0 / 0$ & $0 / 0$ & $0 / 0$ & $0 / 1$ & $0 / 0$ & $0 / 0$ & $0 / 0$ & $0 / 1$ & $0 / 0$ \\
\hline FES-0084 & $0 / 0$ & $0 / 0$ & $0 / 0$ & $0 / 0$ & $0 / 0$ & $0 / 0$ & $0 / 1$ & $0 / 0$ & $0 / 0$ & $0 / 0$ & $0 / 1$ & $0 / 0$ & $0 / 0$ & $0 / 0$ \\
\hline FES-0085 & $0 / 0$ & $0 / 0$ & $0 / 0$ & $0 / 0$ & $0 / 0$ & $0 / 0$ & $0 / 1$ & $0 / 0$ & $0 / 1$ & $0 / 0$ & $0 / 0$ & $0 / 0$ & $0 / 0$ & $0 / 0$ \\
\hline FES-0086 & $0 / 0$ & $0 / 0$ & $0 / 0$ & $0 / 0$ & $0 / 0$ & $0 / 0$ & $0 / 0$ & $0 / 0$ & $0 / 1$ & $0 / 0$ & $0 / 0$ & $0 / 0$ & $0 / 0$ & $0 / 0$ \\
\hline FES-0087 & $0 / 0$ & $0 / 0$ & $0 / 0$ & $0 / 0$ & $0 / 0$ & $0 / 0$ & $0 / 1$ & $0 / 0$ & $1 / 1$ & $0 / 0$ & $0 / 0$ & $0 / 0$ & $0 / 0$ & $0 / 0$ \\
\hline FES-0088 & $0 / 0$ & $0 / 0$ & $0 / 0$ & $0 / 0$ & $0 / 0$ & $0 / 0$ & $1 / 1$ & $0 / 0$ & $0 / 0$ & $0 / 0$ & $0 / 0$ & $0 / 0$ & $0 / 0$ & $0 / 0$ \\
\hline FES-0089 & $0 / 0$ & $0 / 0$ & $0 / 0$ & $0 / 0$ & $0 / 0$ & $0 / 0$ & $0 / 1$ & $0 / 0$ & $0 / 0$ & $0 / 0$ & $0 / 0$ & $0 / 0$ & $0 / 0$ & $0 / 0$ \\
\hline FES-0090 & $0 / 0$ & $0 / 0$ & $0 / 0$ & $0 / 0$ &. & $0 / 0$ & $0 / 0$ & $0 / 0$ & $0 / 0$ & $0 / 0$ & $\%$ & $0 / 0$ & $0 / 0$ & $0 / 0$ \\
\hline FES-0091 & $0 / 0$ & $0 / 0$ & $0 / 0$ & $0 / 0$ & $0 / 1$ & $0 / 0$ & $0 / 0$ & $0 / 0$ & $1 / 1$ & $0 / 1$ & $0 / 0$ & $0 / 0$ & $0 / 0$ & $0 / 1$ \\
\hline FES-0092 & $0 / 0$ & $0 / 0$ & $0 / 0$ & $0 / 0$ & $0 / 0$ & $0 / 0$ & $1 / 1$ & $0 / 0$ & $0 / 0$ & $0 / 0$ & $0 / 0$ & $0 / 0$ & $0 / 0$ & $0 / 0$ \\
\hline FES-0093 & $0 / 0$ & $0 / 0$ & $0 / 0$ & $0 / 0$ & $0 / 1$ & $0 / 0$ & $0 / 1$ & $0 / 0$ & $1 / 1$ & $0 / 0$ & $0 / 1$ & $0 / 0$ & $0 / 0$ & $0 / 0$ \\
\hline FES-0094 & $0 / 0$ & $0 / 0$ & $0 / 0$ & $0 / 0$ & $0 / 0$ & $0 / 0$ & $0 / 0$ & $0 / 0$ & $1 / 1$ & $0 / 0$ & $0 / 0$ & $0 / 0$ & $0 / 0$ & $0 / 0$ \\
\hline FES-0095 & $0 / 0$ & $0 / 0$ & $0 / 0$ & $0 / 0$ & $0 / 0$ & $0 / 0$ & $0 / 0$ & $0 / 0$ & $0 / 0$ & $0 / 0$ & $0 / 0$ & $0 / 0$ & $0 / 0$ & $0 / 0$ \\
\hline FES-0096 & $0 / 0$ & $0 / 0$ & $0 / 0$ & $0 / 0$ & $0 / 1$ & $0 / 0$ & $0 / 0$ & $0 / 0$ & $0 / 0$ & $0 / 0$ & $0 / 0$ & $0 / 0$ & $0 / 1$ & $0 / 0$ \\
\hline FES-0097 & $0 / 0$ & $0 / 0$ & $0 / 0$ & $0 / 0$ & $0 / 1$ & $0 / 0$ & $0 / 0$ & $0 / 0$ & $0 / 0$ & $0 / 0$ & $0 / 0$ & $0 / 0$ & $0 / 0$ & $0 / 0$ \\
\hline FES-0098 & $0 / 0$ & $0 / 0$ & $0 / 0$ & $0 / 0$ & $0 / 0$ & $0 / 0$ & $0 / 0$ & $0 / 0$ & $1 / 1$ & $0 / 0$ & $0 / 0$ & $0 / 0$ & $0 / 0$ & $0 / 0$ \\
\hline FES-0099 & $0 / 0$ & $0 / 0$ & $0 / 0$ & $0 / 0$ & $0 / 0$ & $0 / 0$ & $0 / 1$ & $0 / 0$ & $0 / 0$ & $0 / 0$ & $0 / 0$ & $0 / 0$ & $0 / 0$ & $0 / 0$ \\
\hline FES-0100 & $0 / 0$ & $0 / 0$ & $0 / 0$ & $0 / 0$ & $0 / 0$ & $0 / 0$ & $0 / 0$ & $0 / 0$ & $0 / 1$ & $0 / 0$ & $0 / 0$ & $0 / 0$ & $0 / 1$ & $0 / 1$ \\
\hline FES-0101 & $0 / 0$ & $0 / 0$ & $0 / 0$ & $0 / 0$ & $0 / 0$ & $0 / 0$ & $0 / 0$ & $0 / 0$ & $0 / 1$ & $0 / 0$ & $0 / 0$ & $0 / 0$ & $0 / 0$ & $0 / 0$ \\
\hline FES-0102 & $0 / 0$ & $0 / 0$ & $0 / 0$ & $0 / 0$ & $0 / 1$ & $0 / 0$ & $0 / 0$ & $0 / 0$ & $0 / 1$ & $0 / 0$ & $0 / 0$ & $0 / 0$ & $0 / 0$ & $0 / 0$ \\
\hline FES-0103 & $0 / 0$ & $0 / 0$ & $0 / 0$ & $0 / 0$ & $0 / 1$ & $0 / 0$ & $0 / 1$ & $0 / 0$ & $0 / 1$ & $0 / 0$ & $0 / 0$ & $0 / 0$ & $0 / 1$ & $0 / 0$ \\
\hline FES-0104 & $0 / 0$ & $0 / 0$ & $0 / 0$ & $0 / 0$ & $0 / 0$ & $0 / 0$ & 0/1 & $0 / 0$ & $0 / 0$ & 0/0 & $0 / 0$ & $0 / 0$ & $0 / 0$ & $0 / 0$ \\
\hline
\end{tabular}


Продолжение таблицы 2

\begin{tabular}{|c|c|c|c|c|c|c|c|c|c|c|c|c|c|c|}
\hline rs2378249 & rs12896399 & rs1393350 & rs683 & rs3114908 & rs1800414 & rs10756819 & rs17128291 & rs1129038 & rs1667394 & rs1126809 & rs1470608 & rs1426654 & rs6059655 & rs 8051733 \\
\hline $\begin{array}{l}\text { глаз и } \\
\text { волос }\end{array}$ & $\begin{array}{l}\text { глаз и } \\
\text { волос }\end{array}$ & $\begin{array}{l}\text { глаз и } \\
\text { волос }\end{array}$ & $\begin{array}{l}\text { глаз и } \\
\text { волос }\end{array}$ & $\begin{array}{l}\text { глаз и } \\
\text { волос }\end{array}$ & кожи & кожи & кожи & кожи & кожи & кожи & кожи & кожи & кожи & кожи \\
\hline 20 & 14 & 11 & 9 & 16 & 15 & 9 & 14 & 15 & 15 & 11 & 15 & 15 & 20 & 16 \\
\hline 33218090 & 92773663 & 89011046 & 12709305 & 89383725 & 28197037 & 16858084 & 92882826 & 28356859 & 28530182 & 89017961 & 28288121 & 48426484 & 32665748 & 90024206 \\
\hline A & c & $G$ & c & $G$ & A & A & A & $G$ & A & $\mathrm{G}$ & A & A & $G$ & A \\
\hline G & A & $A$ & A & A & $\mathrm{G}$ & G & G & A & G & $A$ & c & G & A & $\mathrm{G}$ \\
\hline $0 / 0$ & $0 / 0$ & 0/0 & $0 / 1$ & $0 / 0$ & $0 / 0$ & $0 / 1$ & $0 / 1$ & $0 / 0$ & $0 / 0$ & $0 / 0$ & $0 / 0$ & $1 / 1$ & $0 / 0$ & $0 / 0$ \\
\hline $0 / 1$ & $0 / 0$ & $0 / 0$ & $0 / 0$ & $0 / 0$ & $0 / 0$ & $0 / 1$ & $0 / 1$ & $0 / 0$ & $1 / 1$ & $0 / 0$ & $0 / 0$ & $0 / 1$ & $0 / 0$ & $0 / 1$ \\
\hline $0 / 0$ & $0 / 0$ & $0 / 0$ & $0 / 0$ & $0 / 0$ & $0 / 0$ & $1 / 1$ & $0 / 0$ & $0 / 0$ & $1 / 1$ & $0 / 0$ & $0 / 0$ & $1 / 1$ & $0 / 0$ & $0 / 1$ \\
\hline $0 / 1$ & $0 / 1$ & $0 / 0$ & $0 / 0$ & $0 / 0$ & $0 / 0$ & $0 / 0$ & $0 / 0$ & $0 / 0$ & $0 / 1$ & $0 / 0$ & $0 / 0$ & $1 / 1$ & $0 / 0$ & $0 / 0$ \\
\hline $0 / 0$ & $1 / 1$ & $0 / 0$ & $0 / 0$ & $0 / 1$ & $0 / 0$ & $0 / 1$ & $0 / 1$ & $0 / 0$ & $1 / 1$ & $0 / 0$ & $0 / 0$ & $0 / 1$ & $0 / 0$ & $0 / 0$ \\
\hline $0 / 0$ & $0 / 1$ & $0 / 0$ & $0 / 0$ & $0 / 0$ & $0 / 0$ & $0 / 0$ & $0 / 1$ & $0 / 0$ & $0 / 1$ & $0 / 0$ & $0 / 1$ & $0 / 1$ & $0 / 0$ & $0 / 0$ \\
\hline $0 / 1$ & $0 / 0$ & $0 / 0$ & $0 / 0$ & $0 / 0$ & $0 / 0$ & $1 / 1$ & $0 / 0$ & $0 / 0$ & $1 / 1$ & $0 / 0$ & $0 / 0$ & $1 / 1$ & o/0 & $0 / 1$ \\
\hline $0 / 0$ & $1 / 1$ & $0 / 0$ & $0 / 1$ & $1 / 1$ & $0 / 0$ & $0 / 0$ & $0 / 0$ & $0 / 0$ & $0 / 1$ & $0 / 0$ & $0 / 0$ & $1 / 1$ & $0 / 0$ & $0 / 0$ \\
\hline $0 / 1$ & $1 / 1$ & $0 / 0$ & $0 / 0$ & $0 / 0$ & $0 / 0$ & $0 / 0$ & $0 / 0$ & $0 / 0$ & $1 / 1$ & $0 / 0$ & $0 / 0$ &. & $0 / 0$ & $0 / 0$ \\
\hline $0 / 1$ & $0 / 0$ & $0 / 0$ & $0 / 0$ & $0 / 0$ & $0 / 0$ & $0 / 1$ & $1 / 1$ & $0 / 0$ & $0 / 1$ & $0 / 0$ & $0 / 0$ & $1 / 1$ & $0 / 0$ & $0 / 1$ \\
\hline $0 / 1$ & $0 / 0$ & $0 / 0$ & $0 / 0$ & $1 / 1$ & $0 / 0$ & $1 / 1$ & $0 / 0$ & $0 / 0$ & $1 / 1$ & $0 / 0$ & $0 / 0$ & $1 / 1$ & $0 / 0$ & $0 / 1$ \\
\hline $0 / 0$ & $0 / 1$ & $0 / 0$ & $0 / 0$ & $0 / 1$ & $0 / 0$ & $0 / 0$ & $0 / 0$ & $0 / 0$ & $1 / 1$ & $0 / 0$ & $0 / 0$ & $1 / 1$ & $0 / 0$ & $0 / 1$ \\
\hline $0 / 1$ & $1 / 1$ & $0 / 0$ & $0 / 1$ & $0 / 1$ & $0 / 0$ & $0 / 1$ & $0 / 0$ & $0 / 1$ & $0 / 0$ & $0 / 0$ & $0 / 1$ & $0 / 1$ & $0 / 0$ & $0 / 0$ \\
\hline $1 / 1$ & $0 / 1$ & $0 / 0$ & $0 / 0$ & $1 / 1$ & 0/0 & $1 / 1$ & $0 / 0$ & $0 / 0$ & $0 / 0$ & $0 / 0$ & $0 / 1$ & $1 / 1$ & $0 / 0$ & $0 / 0$ \\
\hline $0 / 0$ & $1 / 1$ & $0 / 0$ & $0 / 0$ & $0 / 1$ & $0 / 1$ & $0 / 1$ & $0 / 0$ & $0 / 0$ & $0 / 1$ & $0 / 0$ & $0 / 0$ & $0 / 1$ & $0 / 0$ & $0 / 1$ \\
\hline $1 / 1$ & $0 / 0$ & $0 / 0$ & $0 / 1$ & $0 / 1$ & $0 / 0$ & $0 / 1$ & $0 / 0$ & $0 / 0$ & $1 / 1$ & $0 / 1$ & $1 / 1$ & $0 / 1$ & $0 / 0$ & $0 / 0$ \\
\hline $0 / 1$ & $0 / 0$ & $0 / 0$ & $0 / 1$ & $1 / 1$ & $0 / 0$ & $0 / 0$ & $0 / 0$ & $1 / 1$ & $0 / 0$ & $0 / 0$ & $1 / 1$ & $0 / 1$ & $0 / 0$ & $0 / 0$ \\
\hline $0 / 0$ & $0 / 0$ & $0 / 0$ & $0 / 0$ & $0 / 1$ & $0 / 0$ & $0 / 1$ & $0 / 0$ & $0 / 1$ & $0 / 1$ & $0 / 0$ & $0 / 1$ & $1 / 1$ & $0 / 0$ & $0 / 1$ \\
\hline $0 / 1$ & $0 / 1$ & $0 / 0$ & $0 / 1$ & $0 / 1$ & $0 / 0$ & $0 / 1$ & $0 / 0$ & $0 / 1$ & $0 / 0$ & $0 / 0$ & $1 / 1$ & $0 / 1$ & $0 / 0$ & $0 / 1$ \\
\hline $0 / 0$ & $1 / 1$ & $0 / 0$ & $0 / 1$ & $0 / 0$ & $0 / 0$ & $0 / 1$ & $0 / 0$ & $0 / 0$ & $1 / 1$ & $0 / 0$ & $0 / 0$ & $0 / 1$ & $0 / 0$ & $0 / 0$ \\
\hline $0 / 0$ & $0 / 0$ & $0 / 0$ & $0 / 1$ & $0 / 0$ & $0 / 0$ & $0 / 1$ & $0 / 0$ & $0 / 1$ & $0 / 1$ & $0 / 0$ & $0 / 1$ & $0 / 1$ & $0 / 0$ & $0 / 0$ \\
\hline $0 / 0$ & $0 / 1$ & $1 / 1$ & $0 / 0$ & $1 / 1$ & $0 / 0$ & $0 / 0$ & $0 / 0$ & $0 / 1$ & $0 / 0$ & $\%$ & $1 / 1$ & $0 / 0$ & $0 / 0$ & $0 / 0$ \\
\hline $0 / 0$ & $0 / 0$ & $0 / 0$ & $0 / 0$ & $0 / 1$ & $0 / 0$ & $0 / 0$ & $0 / 0$ & $0 / 0$ & $0 / 0$ & $0 / 0$ & $0 / 0$ & $1 / 1$ & $0 / 0$ & $0 / 0$ \\
\hline $0 / 0$ & $0 / 1$ & $0 / 0$ & $0 / 0$ & $0 / 0$ & $0 / 0$ & $1 / 1$ & $0 / 1$ & $0 / 0$ & $0 / 0$ & $0 / 0$ & $0 / 0$ & $1 / 1$ & $0 / 0$ & $0 / 1$ \\
\hline $0 / 0$ & $0 / 1$ & $0 / 0$ & $0 / 0$ & $0 / 1$ & $0 / 0$ & $0 / 1$ & $0 / 0$ & $0 / 0$ & $0 / 1$ & $0 / 0$ & $0 / 1$ & $1 / 1$ & $0 / 0$ & $0 / 0$ \\
\hline $0 / 1$ & $0 / 0$ & $0 / 0$ & $0 / 0$ & $0 / 1$ & $0 / 0$ & $0 / 0$ & $0 / 0$ & $0 / 0$ & $0 / 0$ & $0 / 0$ & $0 / 0$ & $1 / 1$ & $0 / 0$ & $0 / 0$ \\
\hline $0 / 1$ & $0 / 0$ & $0 / 0$ & $0 / 0$ & $0 / 1$ & $0 / 0$ & $0 / 1$ & $0 / 0$ & $0 / 0$ & $0 / 0$ & $0 / 0$ & $0 / 0$ & $1 / 1$ & $0 / 0$ & $0 / 0$ \\
\hline $0 / 1$ & $0 / 0$ & $0 / 0$ & $0 / 0$ & $1 / 1$ & $0 / 0$ & $0 / 1$ & $0 / 0$ & $0 / 0$ & $0 / 1$ & $0 / 0$ & $0 / 0$ & $1 / 1$ & $0 / 0$ & $0 / 0$ \\
\hline $0 / 1$ & $1 / 1$ & $0 / 0$ & $0 / 0$ & $0 / 0$ & $0 / 0$ & $1 / 1$ & $0 / 0$ & $0 / 0$ & $0 / 1$ & $0 / 0$ & $0 / 0$ & $1 / 1$ & $0 / 0$ & $0 / 0$ \\
\hline $0 / 1$ & $0 / 1$ & $0 / 0$ & $0 / 0$ & $0 / 1$ & $0 / 1$ & $0 / 1$ & $0 / 0$ & $0 / 0$ & $0 / 1$ & $0 / 0$ & $0 / 0$ & $1 / 1$ & $0 / 0$ & $0 / 0$ \\
\hline $0 / 1$ & $0 / 0$ & $0 / 0$ & $0 / 0$ & $1 / 1$ & $0 / 0$ & $0 / 1$ & $0 / 0$ & $0 / 0$ & $0 / 0$ &. & $0 / 0$ & $1 / 1$ & $0 / 0$ & $1 / 1$ \\
\hline $0 / 0$ & $0 / 1$ & $0 / 0$ & $0 / 1$ & $0 / 0$ & $0 / 0$ & $0 / 0$ & $0 / 0$ & $0 / 0$ & $0 / 1$ & $\%$ & $0 / 1$ & $0 / 1$ & $0 / 0$ & $0 / 0$ \\
\hline $0 / 0$ & $0 / 0$ & $0 / 0$ & $0 / 1$ & $0 / 0$ & $0 / 0$ & $0 / 1$ & $0 / 0$ & $0 / 0$ & $1 / 1$ & $\%$ & $0 / 0$ & $0 / 1$ & $0 / 0$ & $0 / 0$ \\
\hline $0 / 1$ & $0 / 1$ & $0 / 0$ & $0 / 0$ & $0 / 0$ & $0 / 0$ & $1 / 1$ & $0 / 0$ & $0 / 0$ & $1 / 1$ &. & $0 / 0$ & $1 / 1$ & $0 / 0$ & $0 / 0$ \\
\hline $0 / 1$ & $0 / 0$ & $0 / 0$ & $0 / 0$ & $1 / 1$ & $0 / 0$ & $0 / 1$ & $0 / 0$ & $0 / 0$ & $0 / 1$ &. & $0 / 1$ & $1 / 1$ & $0 / 0$ & $0 / 0$ \\
\hline $0 / 0$ & $0 / 1$ & $0 / 0$ & $0 / 0$ & $0 / 1$ & $0 / 1$ & $0 / 0$ & $0 / 1$ & $0 / 0$ & $0 / 1$ &. & $0 / 0$ & $1 / 1$ & $0 / 0$ & $0 / 0$ \\
\hline $1 / 1$ & $0 / 0$ & $0 / 0$ & $0 / 0$ & $0 / 1$ & $0 / 0$ & $0 / 1$ & $0 / 0$ & $0 / 0$ & $0 / 0$ & $\%$ & $0 / 0$ & $0 / 1$ & $0 / 0$ & $0 / 0$ \\
\hline $0 / 0$ & $0 / 1$ & $0 / 0$ & $0 / 0$ & $0 / 0$ & $0 / 0$ & $0 / 0$ & $0 / 0$ & $0 / 0$ & $0 / 1$ &. & $0 / 0$ & $1 / 1$ & $0 / 0$ & $0 / 1$ \\
\hline $0 / 0$ & $1 / 1$ & $0 / 0$ & $0 / 0$ & $0 / 0$ & $0 / 0$ & $0 / 0$ & $0 / 0$ & $0 / 1$ & $0 / 0$ & $\%$ & $0 / 1$ & $0 / 1$ & $0 / 0$ & $0 / 0$ \\
\hline $0 / 0$ & $0 / 1$ & $0 / 0$ & $0 / 0$ & $0 / 1$ & $0 / 0$ & $0 / 1$ & $0 / 0$ & $0 / 0$ & $0 / 1$ & $\%$ & $0 / 0$ & $0 / 1$ & $0 / 0$ & $0 / 0$ \\
\hline $0 / 0$ & $0 / 1$ & $0 / 0$ & $0 / 1$ & $1 / 1$ & $0 / 0$ & $0 / 1$ & $0 / 0$ & $0 / 0$ & $0 / 1$ & $\%$ & $0 / 0$ & $1 / 1$ & $0 / 0$ & $0 / 1$ \\
\hline $0 / 0$ & $1 / 1$ & $0 / 0$ & $0 / 1$ & $0 / 0$ & $0 / 0$ & $0 / 1$ & $0 / 0$ & $0 / 0$ & $0 / 1$ & $\%$ & $0 / 0$ & $1 / 1$ & $0 / 0$ & $0 / 0$ \\
\hline $0 / 1$ & $0 / 1$ & $0 / 0$ & $0 / 1$ & $0 / 1$ & $0 / 0$ & $0 / 1$ & $0 / 1$ & $0 / 0$ & $1 / 1$ &. & $0 / 0$ & $1 / 1$ & $0 / 0$ & $0 / 0$ \\
\hline $0 / 0$ & $0 / 1$ & $0 / 0$ & $0 / 0$ & $0 / 1$ & $0 / 0$ & $0 / 1$ & $0 / 0$ & 0/0 & $0 / 0$ & $\%$ & $0 / 1$ & $1 / 1$ & o/0 & $0 / 1$ \\
\hline $0 / 0$ & $0 / 0$ & $0 / 0$ & $0 / 1$ & $0 / 0$ & $0 / 0$ & $0 / 1$ & $0 / 0$ & $0 / 0$ & $0 / 1$ & $\%$ & $0 / 0$ & $1 / 1$ & $0 / 0$ & $0 / 1$ \\
\hline $0 / 1$ & $1 / 1$ & $0 / 0$ & $0 / 0$ & $0 / 0$ & $0 / 0$ & $1 / 1$ & $0 / 0$ & $0 / 0$ & $1 / 1$ & $\%$ & $0 / 0$ & $1 / 1$ & $0 / 0$ & $0 / 0$ \\
\hline $1 / 1$ & $0 / 0$ & $0 / 0$ & $0 / 1$ & $0 / 0$ & $0 / 0$ & $1 / 1$ & $0 / 0$ & $0 / 0$ & $0 / 1$ &. & $0 / 0$ & $1 / 1$ & $0 / 0$ & $0 / 0$ \\
\hline $1 / 1$ & $0 / 1$ & $0 / 0$ & $0 / 1$ & $0 / 0$ & $0 / 0$ & $1 / 1$ & $0 / 1$ & $0 / 1$ & $0 / 0$ & $\%$ & $0 / 1$ & $0 / 1$ & $0 / 1$ & $0 / 0$ \\
\hline $0 / 1$ & $0 / 0$ & $0 / 0$ & $0 / 0$ & $0 / 0$ & $0 / 0$ & $0 / 0$ & $0 / 0$ & $0 / 0$ & $0 / 1$ & $\%$ & $0 / 1$ & $1 / 1$ & $0 / 0$ & $0 / 0$ \\
\hline $0 / 1$ & $0 / 1$ & $0 / 0$ & $0 / 1$ & $0 / 0$ & $0 / 0$ & $0 / 1$ & $0 / 0$ & $0 / 0$ & $1 / 1$ & $\%$ & $0 / 0$ & $0 / 1$ & $0 / 0$ & $0 / 1$ \\
\hline $1 / 1$ & $0 / 1$ & $0 / 0$ & $0 / 0$ & $0 / 1$ & $0 / 0$ & $0 / 1$ & $0 / 0$ & $0 / 0$ & $0 / 0$ &. & $0 / 0$ & $1 / 1$ & $0 / 1$ & $0 / 1$ \\
\hline $0 / 1$ & $0 / 1$ & $0 / 0$ & $0 / 0$ & $0 / 1$ & $0 / 0$ & $0 / 1$ & $0 / 0$ & $0 / 0$ & $0 / 0$ & $\%$ & $0 / 0$ & $1 / 1$ & $0 / 0$ & $0 / 0$ \\
\hline
\end{tabular}


Продолжение таблицы 2

\begin{tabular}{|c|c|c|c|c|c|c|c|c|c|c|c|c|c|c|}
\hline RS & rs11547464 & rs1805005 & rs1805006 & rs1805007 & rs2228479 & rs 1110400 & rs28777 & rs12821256 & rs4959270 & rs12203592 & rs1042602 & rs1800407 & rs2402130 & rs12913832 \\
\hline $\begin{array}{c}\text { Пред- } \\
\text { сказание } \\
\text { цвета }\end{array}$ & $\begin{array}{l}\text { глаз и } \\
\text { волос }\end{array}$ & $\begin{array}{l}\text { глаз и } \\
\text { волос }\end{array}$ & $\begin{array}{l}\text { глаз и } \\
\text { волос }\end{array}$ & $\begin{array}{l}\text { глаз и } \\
\text { волос }\end{array}$ & $\begin{array}{l}\text { глаз и } \\
\text { волос }\end{array}$ & $\begin{array}{l}\text { глаз и } \\
\text { волос }\end{array}$ & $\begin{array}{l}\text { глаз и } \\
\text { волос }\end{array}$ & $\begin{array}{l}\text { глаз и } \\
\text { волос }\end{array}$ & $\begin{array}{l}\text { глаз и } \\
\text { волос }\end{array}$ & $\begin{array}{l}\text { глаз и } \\
\text { волос }\end{array}$ & $\begin{array}{l}\text { глаз и } \\
\text { волосс }\end{array}$ & $\begin{array}{l}\text { глаз и } \\
\text { волос }\end{array}$ & $\begin{array}{l}\text { глаз и } \\
\text { волос }\end{array}$ & $\begin{array}{l}\text { глаз и } \\
\text { волос }\end{array}$ \\
\hline CHROM & 16 & 16 & 16 & 16 & 16 & 16 & 5 & 12 & 6 & 6 & 11 & 15 & 14 & 15 \\
\hline POS & 89986091 & 89985844 & 89985918 & 89986117 & 89985940 & 89986130 & 33958959 & 89328335 & 457748 & 396321 & 88911696 & 28230318 & 92801203 & 28365618 \\
\hline REF & G & $\mathrm{c}$ & c & $G$ & G & A & c & A & c & G & $\mathrm{c}$ & $G$ & A & A \\
\hline ALT & A & A & A & A & A & G & A & G & A & A & A & A & $G$ & $G$ \\
\hline FES-0105 & $0 / 0$ & $0 / 0$ & $0 / 0$ & $0 / 0$ & $0 / 0$ & $0 / 0$ & $0 / 0$ & $0 / 0$ & $0 / 0$ & $0 / 0$ & $0 / 0$ & $0 / 0$ & $0 / 0$ & $0 / 0$ \\
\hline FES-0106 & $0 / 0$ & $0 / 0$ & $0 / 0$ & $0 / 0$ & $0 / 0$ & $0 / 0$ & $0 / 0$ & $0 / 0$ & $0 / 0$ & $0 / 0$ & $0 / 0$ & $0 / 0$ & $0 / 0$ & $0 / 0$ \\
\hline FES-0107 & $0 / 0$ & $0 / 0$ & $0 / 0$ & $0 / 0$ & $0 / 1$ & $0 / 0$ & $0 / 1$ & $0 / 0$ & $0 / 0$ & $0 / 0$ & $0 / 0$ & $0 / 0$ & $0 / 0$ & $0 / 0$ \\
\hline FES-0108 & $0 / 0$ & $0 / 0$ & $0 / 0$ & $0 / 0$ & 0/1 & $0 / 0$ & $0 / 0$ & $0 / 0$ & $0 / 1$ & $0 / 0$ & $0 / 0$ & $0 / 0$ & $0 / 1$ & $0 / 0$ \\
\hline FES-0109 & $0 / 0$ & $0 / 0$ & $0 / 0$ & $0 / 1$ & $0 / 0$ & $0 / 0$ & $0 / 1$ & $0 / 0$ & $0 / 1$ & $0 / 0$ & $0 / 1$ & $0 / 0$ & $0 / 0$ & $0 / 0$ \\
\hline FES-0110 & $0 / 0$ & $0 / 0$ & $0 / 0$ & $0 / 0$ & $0 / 0$ & $0 / 0$ & $0 / 1$ & $0 / 0$ & $0 / 1$ & $0 / 0$ & $0 / 1$ & $0 / 0$ & $0 / 0$ & $0 / 1$ \\
\hline FES-0111 & $0 / 0$ & $0 / 0$ & $0 / 0$ & $0 / 0$ & 0/0 & $0 / 0$ & $1 / 1$ & $0 / 0$ & $0 / 1$ & 0/1 & $0 / 0$ & $0 / 0$ & $0 / 0$ & $0 / 1$ \\
\hline FES-0112 & $0 / 0$ & $0 / 0$ & $0 / 0$ & $0 / 0$ & $0 / 0$ & $0 / 0$ & $0 / 1$ & $0 / 0$ & $0 / 0$ & $0 / 0$ & $0 / 0$ & $0 / 0$ & $0 / 0$ & $0 / 1$ \\
\hline FES-0113 & $0 / 0$ & $0 / 0$ & $0 / 0$ & $0 / 0$ & $0 / 1$ & $0 / 0$ & $0 / 1$ & $0 / 0$ & $0 / 0$ & $0 / 0$ & $0 / 0$ & $0 / 0$ & $0 / 0$ & $0 / 1$ \\
\hline FES-0114 & $0 / 0$ & $0 / 0$ & $0 / 0$ & $0 / 0$ & $0 / 0$ & $0 / 0$ & $1 / 1$ & $0 / 0$ & $0 / 1$ & $0 / 0$ & $0 / 1$ & $0 / 0$ & $0 / 0$ & $0 / 1$ \\
\hline FES-0115 & $0 / 0$ & $0 / 0$ & $0 / 0$ & $0 / 0$ & $0 / 1$ & $0 / 0$ & $0 / 1$ & $0 / 0$ & $0 / 0$ & $0 / 0$ & $0 / 0$ & $0 / 0$ & $0 / 0$ & $0 / 1$ \\
\hline FES-0116 & $0 / 0$ & $0 / 0$ & $0 / 0$ & $0 / 0$ & $0 / 0$ & $0 / 0$ & $0 / 1$ & $0 / 1$ & $0 / 1$ & $0 / 1$ & $0 / 1$ & $0 / 0$ & $0 / 0$ & $0 / 0$ \\
\hline FES-0117 & $0 / 0$ & $0 / 0$ & $0 / 0$ & $0 / 0$ & $0 / 0$ & $0 / 0$ & $1 / 1$ & $0 / 0$ & $1 / 1$ & $0 / 0$ & $0 / 0$ & $0 / 0$ & $0 / 0$ & $0 / 1$ \\
\hline FES-0118 & $0 / 0$ & $0 / 0$ & $0 / 0$ & $0 / 0$ & $0 / 1$ & $0 / 0$ & $0 / 1$ & $0 / 0$ & $0 / 0$ & $0 / 0$ & $0 / 0$ & $0 / 0$ & $0 / 1$ & $1 / 1$ \\
\hline FES-0119 & $0 / 0$ & $0 / 1$ & $0 / 0$ & $0 / 0$ & $0 / 1$ & $0 / 0$ & $1 / 1$ & $0 / 0$ & $0 / 1$ & $0 / 1$ & $0 / 1$ & $0 / 1$ & $0 / 0$ & $0 / 0$ \\
\hline FES-0120 & $0 / 0$ & $0 / 0$ & $0 / 0$ & $0 / 0$ & $0 / 0$ & $0 / 0$ & $0 / 1$ & $0 / 0$ & $0 / 0$ & $0 / 0$ & $0 / 0$ & $0 / 0$ & $0 / 0$ & $1 / 1$ \\
\hline FES-0121 & $0 / 0$ & $0 / 0$ & $0 / 0$ & $0 / 0$ & $0 / 0$ & $0 / 0$ & $1 / 1$ & $0 / 0$ & $1 / 1$ & $0 / 0$ & $0 / 0$ & $0 / 0$ & $0 / 0$ & $1 / 1$ \\
\hline FES-0122 & $0 / 0$ & $0 / 0$ & $0 / 0$ & $0 / 0$ & $1 / 1$ & $0 / 0$ & $1 / 1$ & $0 / 0$ & $0 / 1$ & $0 / 0$ & $0 / 0$ & $0 / 0$ & $0 / 0$ & $0 / 1$ \\
\hline FES-0123 & $0 / 0$ & $0 / 0$ & $0 / 0$ & $0 / 0$ & $0 / 0$ & $0 / 0$ & $1 / 1$ & $0 / 0$ & $0 / 1$ & $0 / 0$ & $1 / 1$ & $0 / 0$ & $0 / 0$ & $0 / 1$ \\
\hline FES-0124 & $0 / 0$ & $0 / 0$ & $0 / 0$ & $0 / 0$ & 0/1 & $0 / 0$ & $1 / 1$ & $0 / 0$ & $0 / 0$ & $0 / 0$ & $0 / 1$ & $0 / 0$ & $0 / 0$ & $1 / 1$ \\
\hline FES-0125 & $0 / 0$ & $0 / 0$ & $0 / 0$ & $0 / 0$ & $0 / 1$ & $0 / 0$ & $1 / 1$ & $0 / 0$ & $0 / 1$ & $0 / 0$ & $0 / 1$ & $0 / 0$ & $0 / 0$ & $0 / 1$ \\
\hline FES-0126 & $0 / 1$ & $0 / 1$ & $\%$ & $\%$ & $0 / 1$ & $0 / 0$ & $0 / 1$ & $0 / 0$ & $0 / 0$ & $0 / 0$ & $0 / 0$ & $0 / 0$ & $0 / 0$ & $0 / 1$ \\
\hline FES-0127 & $0 / 0$ & $0 / 0$ & $0 / 0$ & $0 / 0$ & $0 / 1$ & $0 / 0$ & $0 / 1$ & $0 / 1$ & $0 / 0$ & $0 / 0$ & $0 / 0$ & $0 / 0$ & $0 / 0$ & $0 / 0$ \\
\hline FES-0128 & $0 / 0$ & $0 / 0$ & $0 / 0$ & $0 / 0$ & $0 / 0$ & $0 / 0$ & $1 / 1$ & $0 / 0$ & $0 / 0$ & $0 / 0$ & $1 / 1$ & $0 / 0$ & $0 / 0$ & $0 / 1$ \\
\hline FES-0129 & $0 / 0$ & $0 / 0$ & $0 / 0$ & $0 / 0$ & $0 / 0$ & $0 / 1$ & $0 / 1$ & $\%$ & $1 / 1$ & $0 / 1$ & $0 / 1$ & $0 / 0$ & $\%$ & $1 / 1$ \\
\hline FES-0130 & $0 / 0$ & $0 / 0$ & $0 / 0$ & $0 / 0$ & $0 / 0$ & $0 / 0$ & $1 / 1$ & $0 / 0$ & $1 / 1$ & $0 / 0$ & $0 / 0$ & $0 / 0$ & $0 / 0$ & $1 / 1$ \\
\hline FES-0131 & $0 / 0$ & $0 / 0$ & $0 / 0$ & $0 / 0$ & $0 / 0$ & $0 / 0$ & $1 / 1$ & $0 / 0$ & $0 / 1$ & $0 / 0$ & $0 / 1$ & 0/1 & $0 / 0$ & $1 / 1$ \\
\hline FES-0132 & $0 / 0$ & $0 / 0$ & $0 / 0$ & $0 / 0$ & $0 / 0$ & $0 / 0$ & $0 / 1$ & $0 / 0$ & $0 / 0$ & $0 / 0$ & $0 / 0$ & $0 / 0$ & $0 / 0$ & $0 / 1$ \\
\hline FES-0133 & $0 / 0$ & $0 / 0$ & $0 / 0$ & $0 / 0$ & $0 / 0$ & $0 / 0$ & $0 / 1$ & $0 / 0$ & $0 / 0$ & $0 / 0$ & $0 / 1$ & $0 / 0$ & $0 / 0$ & $1 / 1$ \\
\hline FES-0134 & $0 / 0$ & $0 / 0$ & $0 / 0$ & $0 / 0$ & $0 / 0$ & $0 / 0$ & $1 / 1$ & $0 / 0$ & $0 / 0$ & $0 / 0$ & $0 / 1$ & $0 / 0$ & $0 / 1$ & $1 / 1$ \\
\hline FES-0135 & $1 / 1$ & $1 / 1$ & $1 / 1$ & $0 / 1$ & $\%$ & $0 / 0$ & $\%$ & $0 / 0$ & $\%$ & $0 / 1$ & $0 / 1$ & $0 / 1$ & $0 / 1$ & $0 / 1$ \\
\hline FES-0136 & $0 / 0$ & $0 / 0$ & $0 / 0$ & $0 / 0$ & $0 / 0$ & $0 / 0$ & $1 / 1$ & $0 / 0$ & $1 / 1$ & $0 / 1$ & $0 / 0$ & $0 / 0$ & $0 / 1$ & $1 / 1$ \\
\hline FES-0137 & $0 / 0$ & $0 / 0$ & $0 / 0$ & $0 / 0$ & $0 / 1$ & $0 / 0$ & $1 / 1$ & $0 / 0$ & $0 / 1$ & $0 / 0$ & $1 / 1$ & $0 / 0$ & $0 / 1$ & $1 / 1$ \\
\hline FES-0138 & $0 / 0$ & $0 / 0$ & $0 / 0$ & $0 / 0$ & $0 / 0$ & $0 / 0$ & $1 / 1$ & 0/0 & $0 / 1$ & $0 / 0$ & $0 / 1$ & $0 / 0$ & $0 / 1$ & $1 / 1$ \\
\hline FES-0139 & $0 / 0$ & $\%$ & $0 / 0$ & $0 / 0$ & $0 / 0$ & $0 / 0$ & $1 / 1$ & $0 / 0$ & $0 / 1$ & $0 / 0$ & $0 / 0$ & $0 / 0$ & $0 / 0$ & $1 / 1$ \\
\hline FES-0140 & $0 / 0$ & $0 / 0$ & $0 / 0$ & $0 / 0$ & $0 / 1$ & $0 / 0$ & $1 / 1$ & $0 / 0$ & $0 / 1$ & $0 / 0$ & $0 / 1$ & $0 / 0$ & $0 / 0$ & $1 / 1$ \\
\hline FES-0141 & $0 / 0$ & $0 / 0$ & $0 / 0$ & $0 / 0$ & $0 / 1$ & $0 / 0$ & $1 / 1$ & $0 / 1$ & $0 / 1$ & $0 / 1$ & $0 / 1$ & $0 / 1$ & $0 / 0$ & $1 / 1$ \\
\hline FES-0142 & $0 / 0$ & $0 / 0$ & $0 / 0$ & $0 / 1$ & $0 / 0$ & $0 / 0$ & $1 / 1$ & $0 / 0$ & $0 / 1$ & $0 / 1$ & $0 / 1$ & $0 / 1$ & $0 / 0$ & $1 / 1$ \\
\hline FES-0143 & $0 / 0$ & $0 / 0$ & $0 / 0$ & $0 / 0$ & $0 / 0$ & $0 / 0$ & $1 / 1$ & $0 / 0$ & $0 / 0$ & $0 / 0$ & $0 / 0$ & $0 / 0$ & $0 / 0$ & $1 / 1$ \\
\hline FES-0144 & $0 / 0$ & $0 / 0$ & $0 / 0$ & $0 / 0$ & $0 / 0$ & $0 / 0$ & $1 / 1$ & $0 / 0$ & $0 / 1$ & $0 / 0$ & $0 / 0$ & $0 / 0$ & $0 / 0$ & $1 / 1$ \\
\hline
\end{tabular}

шкалы, состоящие из пяти градаций пигментации глаз и волос, конвертировали в трехградационные шкалы, чтобы фенотипирование было сопоставимо с результатами по HirisPlex-S.

Для того чтобы проанализировать точность результатов предсказаний, полученных с помощью системы HlrisPlex-S, оценивали следующие параметры качества алгоритма:

- precision (отношение истинно положительных значений к общему количеству образцов, которые классификатор отнес к данному классу);

- recall (отношение количества истинно положительных значений к общему количеству образцов этого класса);
- accuracy (доля данных, для которых класс был определен правильно);

- $\mathrm{F}_{1}$-мера (среднее гармоническое между precision и recall классификатора);

- показатели AUC (area under curve - площадь под кривой) для ROC-кривых (график зависимости доли истинно положительных результатов относительно общего количества образцов от доли ложноположительных значений относительно общего количества образцов при варьировании порога решающего правила).

Значения этих оценок качества представлены в табл. 3 и 4. 
Окончание таблицы 2

\begin{tabular}{|c|c|c|c|c|c|c|c|c|c|c|c|c|c|c|}
\hline rs2378249 & rs12896399 & rs1393350 & rs683 & rs 3114908 & rs 1800414 & rs10756819 & rs17128291 & rs1129038 & rs1667394 & rs1126809 & rs1470608 & rs1426654 & rs6059655 & rs8051733 \\
\hline $\begin{array}{l}\text { глаз и } \\
\text { волос }\end{array}$ & $\begin{array}{l}\text { глаз и } \\
\text { волос }\end{array}$ & $\begin{array}{l}\text { глаз и } \\
\text { волос }\end{array}$ & $\begin{array}{l}\text { глаз и } \\
\text { волос }\end{array}$ & $\begin{array}{l}\text { глаз и } \\
\text { волос }\end{array}$ & кожи & кожи & кожи & кожи & кожи & кожи & кожи & кожи & кожи & кожи \\
\hline 20 & 14 & 11 & 9 & 16 & 15 & 9 & 14 & 15 & 15 & 11 & 15 & 15 & 20 & 16 \\
\hline 33218090 & 92773663 & 89011046 & 12709305 & 89383725 & 28197037 & 16858084 & 92882826 & 28356859 & 28530182 & 89017961 & 28288121 & 48426484 & 32665748 & 90024206 \\
\hline A & c & G & c & $G$ & A & A & A & G & A & G & A & A & G & A \\
\hline G & A & A & A & A & G & G & G & A & G & A & c & G & A & G \\
\hline $0 / 0$ & $0 / 0$ & $0 / 0$ & $0 / 0$ & $0 / 0$ & $0 / 0$ & $0 / 0$ & $0 / 1$ & $0 / 0$ & $0 / 1$ & $\%$ & $0 / 0$ & $1 / 1$ & o/0 & $0 / 0$ \\
\hline $0 / 0$ & $0 / 0$ & $0 / 0$ & $0 / 1$ & $0 / 1$ & $0 / 0$ & $0 / 0$ & $0 / 0$ & $0 / 0$ & $0 / 1$ &. & $0 / 0$ & $1 / 1$ & $0 / 0$ & $0 / 0$ \\
\hline $1 / 1$ & $1 / 1$ & $0 / 0$ & $0 / 0$ & $0 / 0$ & $0 / 0$ & $0 / 1$ & $0 / 0$ & $0 / 0$ & $0 / 1$ &. & $0 / 0$ & $1 / 1$ & o/0 & $0 / 1$ \\
\hline $0 / 1$ & $0 / 0$ & $0 / 0$ & 0/0 & $0 / 0$ & $0 / 0$ & $1 / 1$ & $0 / 1$ & $0 / 0$ & $1 / 1$ & $\%$ & $0 / 1$ & $0 / 1$ & $0 / 0$ & $0 / 0$ \\
\hline $0 / 0$ & $0 / 0$ & 0/0 & $0 / 0$ & $0 / 1$ & $0 / 0$ & $1 / 1$ & $0 / 1$ & $0 / 0$ & $1 / 1$ & $0 / 0$ & $0 / 0$ & $0 / 0$ & o/0 & 0/1 \\
\hline $0 / 0$ & $0 / 0$ & $0 / 0$ & $0 / 0$ & $0 / 1$ & $0 / 0$ & $0 / 0$ & $0 / 0$ & $0 / 1$ & $0 / 1$ & $0 / 0$ & $0 / 1$ & $0 / 0$ & $0 / 0$ & $0 / 0$ \\
\hline $0 / 0$ & $0 / 0$ & $0 / 0$ & $1 / 1$ & $0 / 0$ & $0 / 0$ & $0 / 1$ & $0 / 0$ & $0 / 1$ & $0 / 1$ & $0 / 0$ & $0 / 1$ & $0 / 1$ & $0 / 0$ & $0 / 1$ \\
\hline $0 / 0$ & $0 / 0$ & $0 / 0$ & $0 / 1$ & $0 / 0$ & $0 / 0$ & $0 / 1$ & $0 / 0$ & $0 / 1$ & $0 / 0$ & $0 / 0$ & $1 / 1$ & $0 / 0$ & $0 / 0$ & $0 / 0$ \\
\hline $0 / 0$ & $0 / 1$ & 0/1 & $1 / 1$ & 0/1 & 0/0 & $0 / 0$ & 0/0 & $0 / 1$ & 0/1 & 0/1 & $0 / 1$ & $0 / 0$ & $0 / 0$ & $0 / 1$ \\
\hline $0 / 0$ & $0 / 1$ & $0 / 0$ & $0 / 1$ & $1 / 1$ & $0 / 0$ & $1 / 1$ & $0 / 0$ & $0 / 1$ & $0 / 0$ & $0 / 0$ & $0 / 1$ & $0 / 0$ & $0 / 0$ & $0 / 0$ \\
\hline $0 / 0$ & $0 / 1$ & $0 / 1$ & $1 / 1$ & $0 / 1$ & $0 / 0$ & $0 / 0$ & $0 / 0$ & $0 / 1$ & $0 / 1$ & $0 / 1$ & $0 / 1$ & $0 / 0$ & $0 / 0$ & $0 / 1$ \\
\hline 0/1 & 0/1 & $0 / 0$ & $0 / 1$ & $0 / 0$ & $0 / 0$ & $0 / 1$ & $0 / 0$ & $0 / 0$ & $1 / 1$ & $0 / 0$ & $0 / 0$ & $0 / 0$ & $0 / 0$ & $0 / 1$ \\
\hline $0 / 0$ & $0 / 0$ & $0 / 0$ & $0 / 1$ & $0 / 1$ & $0 / 0$ & $0 / 0$ & $0 / 0$ & $0 / 1$ & $0 / 0$ & $0 / 0$ & $0 / 1$ & o/0 & o/0 & 0/1 \\
\hline $0 / 1$ & $0 / 0$ & $0 / 1$ & $1 / 1$ & $0 / 0$ & $0 / 0$ & $0 / 0$ & $0 / 1$ & $1 / 1$ & $0 / 0$ & $0 / 1$ & $1 / 1$ & $0 / 0$ & $0 / 0$ & $0 / 1$ \\
\hline $0 / 0$ & $0 / 0$ & $0 / 0$ & $1 / 1$ & $0 / 1$ & $0 / 0$ & $0 / 0$ & $0 / 0$ & $0 / 0$ & $1 / 1$ & $0 / 0$ & $0 / 1$ & $1 / 1$ & $0 / 1$ & $0 / 0$ \\
\hline $0 / 0$ & $0 / 0$ & 0/1 & $0 / 0$ & $0 / 0$ & $0 / 0$ & 0/1 & $0 / 0$ & $1 / 1$ & $0 / 0$ & $0 / 1$ & $1 / 1$ & $0 / 0$ & $0 / 0$ & $0 / 0$ \\
\hline $0 / 0$ & $1 / 1$ & 0/1 & $0 / 1$ & $0 / 0$ & 0/0 & $0 / 0$ & $0 / 0$ & $1 / 1$ & $0 / 0$ & 0/1 & 1/1 & $0 / 0$ & o/0 & $1 / 1$ \\
\hline $0 / 0$ & $0 / 0$ & $0 / 0$ & $0 / 1$ & $0 / 1$ & $0 / 0$ & $0 / 0$ & $0 / 0$ & $0 / 1$ & $0 / 0$ & $0 / 0$ & $0 / 1$ & $0 / 0$ & 0/0 & $1 / 1$ \\
\hline $0 / 0$ & 0/1 & $0 / 0$ & $0 / 1$ & $1 / 1$ & $0 / 0$ & 0/1 & $0 / 0$ & $0 / 1$ & $0 / 1$ & $0 / 0$ & $0 / 1$ & $0 / 0$ & $0 / 0$ & $0 / 1$ \\
\hline $0 / 1$ & $1 / 1$ & $0 / 0$ & $0 / 0$ & $0 / 1$ & $0 / 0$ & $0 / 0$ & $0 / 1$ & $1 / 1$ & $0 / 0$ & $0 / 0$ & $1 / 1$ & 0/0 & $0 / 1$ & $0 / 1$ \\
\hline $0 / 1$ & $0 / 0$ & $0 / 0$ & $0 / 1$ & $0 / 1$ & $0 / 0$ & $0 / 0$ & $0 / 0$ & $0 / 1$ & 0/0 & $0 / 0$ & $0 / 1$ & $0 / 0$ & $0 / 0$ & $1 / 1$ \\
\hline $0 / 0$ & $0 / 0$ & 0/1 &. & 0/1 & $0 / 0$ & $1 / 1$ & 0/1 & 0/1 &. & 0/1 & $\%$ & $0 / 0$ & o/0 & 0/0 \\
\hline $0 / 0$ & 0/1 & $0 / 0$ & 0/1 & 0/1 & $0 / 0$ & 0/1 & $0 / 0$ & $0 / 0$ & $0 / 1$ & $0 / 0$ & 0/1 & $0 / 0$ & $0 / 0$ & $1 / 1$ \\
\hline $0 / 1$ & 0/1 & $0 / 0$ & 0/0 & 0/1 & $0 / 0$ & 0/1 & 0/1 & $0 / 1$ & $0 / 0$ & $0 / 0$ & 0/1 & 0/1 & $0 / 1$ & 0/1 \\
\hline $0 / 0$ & $0 / 1$ & $0 / 0$ & $1 / 1$ & $0 / 1$ & $0 / 0$ & $0 / 1$ & $0 / 0$ & $1 / 1$ & $0 / 0$ & $\%$ & $1 / 1$ & $0 / 0$ &. & $0 / 1$ \\
\hline $0 / 0$ & $0 / 1$ & $0 / 0$ & $0 / 1$ & $0 / 0$ & $0 / 0$ & $0 / 1$ & $0 / 0$ & $1 / 1$ & $0 / 0$ & $0 / 0$ & $1 / 1$ & $0 / 0$ & $0 / 0$ & $0 / 0$ \\
\hline $0 / 0$ & $0 / 0$ & $0 / 0$ & $0 / 1$ & 0/1 & $0 / 0$ & $0 / 0$ & $0 / 0$ & $1 / 1$ & $0 / 0$ & o/0 & $1 / 1$ & $0 / 0$ & $0 / 0$ & 0/0 \\
\hline $0 / 1$ & $0 / 1$ & 0/1 & $1 / 1$ & $1 / 1$ & $0 / 0$ & $0 / 1$ & $0 / 0$ & $0 / 1$ & $0 / 0$ & 0/1 & $1 / 1$ & $0 / 0$ & $0 / 0$ & 0/1 \\
\hline $0 / 0$ & 0/1 & $0 / 0$ & $0 / 1$ & $0 / 0$ & $0 / 0$ & $0 / 0$ & $0 / 0$ & $1 / 1$ & $0 / 0$ & $0 / 0$ & $1 / 1$ & $0 / 0$ & $0 / 0$ & 0/1 \\
\hline $0 / 1$ & $0 / 0$ & $0 / 0$ & $0 / 1$ & $0 / 1$ & $0 / 0$ & $0 / 1$ &. & $1 / 1$ & $0 / 0$ & $0 / 0$ & $1 / 1$ & $0 / 0$ & $0 / 0$ & $0 / 0$ \\
\hline $0 / 1$ & $0 / 1$ & $0 / 1$ & $0 / 1$ &. & $\%$ & $\%$ & $0 / 0$ & $1 / 1$ & $0 / 1$ & $1 / 1$ & $0 / 1$ & $0 / 0$ & $1 / 1$ & $0 / 0$ \\
\hline $0 / 0$ & $0 / 1$ & $0 / 1$ & $0 / 0$ & $0 / 1$ & $0 / 0$ & $0 / 1$ & $0 / 0$ & $1 / 1$ & $0 / 0$ & $0 / 1$ & $0 / 1$ & $0 / 0$ & $0 / 0$ & $0 / 0$ \\
\hline $0 / 0$ & $0 / 1$ & $0 / 0$ & $0 / 1$ & $0 / 1$ & $0 / 0$ & $0 / 0$ & $0 / 0$ & $1 / 1$ & $0 / 0$ & $0 / 0$ & $1 / 1$ & $0 / 0$ & $0 / 0$ & $1 / 1$ \\
\hline $0 / 0$ & $0 / 0$ & $0 / 0$ & $1 / 1$ & $0 / 0$ & $0 / 0$ & $0 / 1$ & $1 / 1$ & $1 / 1$ & $0 / 0$ & $0 / 0$ & $1 / 1$ & $0 / 0$ & $0 / 0$ & $0 / 1$ \\
\hline $0 / 1$ & $0 / 0$ & $0 / 1$ & $1 / 1$ & $0 / 1$ & $0 / 0$ & $0 / 1$ & $0 / 0$ & $1 / 1$ & $0 / 0$ & $0 / 1$ & $1 / 1$ & $0 / 0$ & $0 / 0$ & $0 / 1$ \\
\hline $0 / 1$ & $0 / 1$ & $0 / 0$ & $1 / 1$ & $0 / 0$ & $0 / 0$ & $0 / 1$ & $0 / 0$ & $1 / 1$ & $0 / 0$ & $0 / 0$ & $0 / 1$ & $0 / 0$ & $0 / 0$ & $0 / 1$ \\
\hline $0 / 1$ & $1 / 1$ & $0 / 0$ & $0 / 1$ & $0 / 1$ & $0 / 0$ & $0 / 1$ & $0 / 0$ & $0 / 1$ & $0 / 0$ & $0 / 0$ & $1 / 1$ & $0 / 0$ & $0 / 0$ & $0 / 1$ \\
\hline $0 / 0$ & $0 / 0$ & $0 / 0$ & $0 / 1$ & 1/1 & $0 / 0$ & $0 / 1$ & $0 / 0$ & $1 / 1$ & 0/0 & $0 / 0$ & $1 / 1$ & $0 / 0$ & $0 / 0$ & $0 / 1$ \\
\hline $0 / 0$ & $0 / 1$ & $0 / 0$ & $1 / 1$ & $0 / 0$ & $0 / 0$ & $0 / 1$ & 0/0 & $1 / 1$ & 0/0 & $0 / 0$ & $0 / 1$ & $0 / 0$ & $0 / 0$ & $0 / 0$ \\
\hline $0 / 0$ & $0 / 1$ & $0 / 0$ & $0 / 1$ & $1 / 1$ & $0 / 0$ & $0 / 1$ & o/0 & $1 / 1$ & o/0 & $0 / 0$ & $1 / 1$ & $0 / 0$ & $0 / 0$ & $0 / 1$ \\
\hline
\end{tabular}

\section{РЕЗУЛЬТАТЫ ИССЛЕДОВАНИЯ}

Мы провели фотографирование 144 представителей коренного населения Европейской части России и Сибири. Образцы ДНК тех же 144 индивидов были генотипированы по маркерам, входящим в панель HIrisPlex. Составили комбинированную базу, включающую фенотипические и генотипические данные по каждому индивиду.

Для оценки качества стандартной системы предсказания цвета глаз и волос (HlrisPlex-S) на новых фенотипированных популяциях мы предсказали цвет глаз и волос по генотипу, используя онлайн-ресурс [16]. В табл. 5 представлены результаты предсказания цвета глаз для каждого индивида. В целом, табл. 1 и 5 позволяют сравнить реальные и предсказанные фенотипы для каждого отдельного образца. Показатели качества предсказания для всего массива данных представлены в табл. 3.

Значения наиболее часто используемого показателя качества (AUC) по разным классам колеблются от 0,89 до 0,59 и в среднем составляют 0,79. Эти показатели, рассчитанные для популяций России, несколько снижены по сравнению с аналогичными показателями для Западной Европы $(0,89)$. Например, для светлых глаз в Западной Европе AUC составляет 0,94, а в России - 0,89. Снижение 
Таблица 3. Показатели точности панели HIrisPlex для популяций Западной Европы и России

\begin{tabular}{|c|c|c|c|c|c|}
\hline & Для популяций Западной Европы & \multicolumn{4}{|c|}{ Для популяций России } \\
\hline & AUC & AUC & Precision & Accuracy & Recall \\
\hline Светлые глаза & 0,94 & 0,89 & 0,89 & 0,88 & 0,63 \\
\hline Смешанный цвет глаз & 0,74 & - & - & - & - \\
\hline Темные глаза & 0,95 & 0,89 & 0,85 & 0,87 & 0,98 \\
\hline Рыжие волосы & 0,93 & 0,59 & 0,33 & 0,92 & 0,2 \\
\hline Светлые волосы & 0,81 & - & - & - & - \\
\hline Смешанный цвет волос & 0,74 & 0,72 & 0,32 & 0,66 & 0,56 \\
\hline Темные волосы & 0,86 & 0,84 & 0,94 & 0,68 & 0,57 \\
\hline
\end{tabular}

Таблица 4. Показатели точности панели HIrisPlex для регионов России

\begin{tabular}{|l|c|c|}
\hline & Европейская часть России & Сибирь \\
\hline Светлые глаза & 0,89 & 0,57 \\
\hline Темные глаза & 0,86 & 0,56 \\
\hline
\end{tabular}

можно наблюдать по всем классам цвета и глаз, и волос. Отметим, что в связи с малочисленностью в нашей выборке двух фенотипических классов - смешанных оттенков глаз и светлых волос - мы не приводим в таблице показатели точности для этих классов. При необходимости они могут быть рассчитаны из первичных данных табл. 1 и 5. Они еще более снижены по сравнению с аналогичными показателями для Западной Европы, но объем выборки для этих классов - менее пяти индивидов - не позволяет доверять показателям для этих двух классов.

Популяции России генетически чрезвычайно гетерогенны, и мы намеренно включили в выборку генетически контрастные группы коренного населения - Европейской части России и Сибири. Табл. 4 демонстрирует качество предикции цвета глаз HlrisPlex для этих двух метапопуляций (качество предикции цвета волос не оценивали в связи с меньшим объемом выборки, см. Пациенты и методы). Оказалось, что точность предсказания цвета глаз для популяций Европейской части России близка к точности предсказания для объединенной выборки, - можно наблюдать некоторое снижение по сравнению с Западной Европой, но в целом приемлемую точность (AUC около 0,8). Ситуация для популяций Сибири оказалась значительно хуже: показатели AUC около 0,6.

\section{ОБСУЖДЕНИЕ РЕЗУЛЬТАТОВ}

Основой нашего исследования послужила коллекция антропологических фотографий представителей различных групп коренного народонаселения России. Фотографии,

Таблица 5. Фенотипы (цвет глаз и волос), предсказанные по генотипам панели HIrisPlex

\begin{tabular}{|c|c|c|}
\hline Образец & Предсказанный цвет глаз & Предсказанный цвет волос \\
\hline FES-0001 & темный & не анализируется \\
\hline FES-0002 & темный & темные \\
\hline FES-0003 & темный & темные \\
\hline FES-0004 & темный & темные \\
\hline FES-0005 & темный & темные \\
\hline FES-0006 & темный & темные \\
\hline FES-0007 & темный & нет предсказания \\
\hline FES-0008 & темный & не анализируется \\
\hline FES-0009 & темный & темные \\
\hline FES-0010 & темный & темные \\
\hline FES-0011 & темный & не анализируется \\
\hline FES-0012 & темный & темные \\
\hline FES-0013 & темный & темные \\
\hline FES-0014 & темный & темные \\
\hline FES-0015 & темный & темные \\
\hline FES-0016 & темный & темные \\
\hline FES-0017 & темный & темные \\
\hline FES-0018 & темный & не анализируется \\
\hline FES-0019 & темный & не анализируется \\
\hline FES-0020 & темный & не анализируется \\
\hline FES-0021 & темный & темные \\
\hline FES-0022 & темный & темные \\
\hline FES-0023 & темный & промежуточные \\
\hline
\end{tabular}


Продолжение таблицы 5

\begin{tabular}{|c|c|c|}
\hline Образец & Предсказанный цвет глаз & Предсказанный цвет волос \\
\hline FES-0024 & светлый & светлые \\
\hline FES-0025 & темный & промежуточные \\
\hline FES-0026 & светлый & светлые \\
\hline FES-0027 & темный & промежуточные \\
\hline FES-0028 & светлый & рыжие \\
\hline FES-0029 & темный & не анализируется \\
\hline FES-0030 & темный & промежуточные \\
\hline FES-0031 & темный & светлые \\
\hline FES-0032 & темный & промежуточные \\
\hline FES-0033 & темный & промежуточные \\
\hline FES-0034 & темный & не анализируется \\
\hline FES-0035 & темный & промежуточные \\
\hline FES-0036 & темный & не анализируется \\
\hline FES-0037 & темный & промежуточные \\
\hline FES-0038 & темный & светлые \\
\hline FES-0039 & светлый & не анализируется \\
\hline FES-0040 & светлый & промежуточные \\
\hline FES-0041 & светлый & промежуточные \\
\hline FES-0042 & темный & не анализируется \\
\hline FES-0043 & темный & не анализируется \\
\hline FES-0044 & светлый & светлые \\
\hline FES-0045 & темный & не анализируется \\
\hline FES-0046 & темный & промежуточные \\
\hline FES-0047 & темный & не анализируется \\
\hline FES-0048 & темный & не анализируется \\
\hline FES-0049 & темный & темные \\
\hline FES-0050 & темный & промежуточные \\
\hline FES-0051 & темный & не анализируется \\
\hline FES-0052 & темный & не анализируется \\
\hline FES-0053 & темный & не анализируется \\
\hline FES-0054 & темный & темные \\
\hline FES-0055 & темный & не анализируется \\
\hline FES-0056 & темный & не анализируется \\
\hline FES-0057 & темный & не анализируется \\
\hline FES-0058 & темный & не анализируется \\
\hline FES-0059 & темный & не анализируется \\
\hline FES-0060 & темный & не анализируется \\
\hline FES-0061 & темный & не анализируется \\
\hline FES-0062 & темный & не анализируется \\
\hline FES-0063 & темный & не анализируется \\
\hline FES-0064 & темный & не анализируется \\
\hline FES-0065 & темный & не анализируется \\
\hline FES-0066 & темный & промежуточные \\
\hline FES-0067 & темный & не анализируется \\
\hline FES-0068 & темный & не анализируется \\
\hline FES-0069 & светлый & не анализируется \\
\hline FES-0070 & темный & темные \\
\hline FES-0071 & темный & не анализируется \\
\hline FES-0072 & темный & не анализируется \\
\hline FES-0073 & темный & промежуточные \\
\hline FES-0074 & темный & не анализируется \\
\hline
\end{tabular}


ORIGINAL RESEARCH I GENETICS

Продолжение таблицы 5

\begin{tabular}{|c|c|c|}
\hline Образец & Предсказанный цвет глаз & Предсказанный цвет волос \\
\hline FES-0075 & темный & не анализируется \\
\hline FES-0076 & темный & темные \\
\hline FES-0077 & темный & не анализируется \\
\hline FES-0078 & темный & темные \\
\hline FES-0079 & темный & темные \\
\hline FES-0080 & темный & темные \\
\hline FES-0081 & темный & не анализируется \\
\hline FES-0082 & темный & не анализируется \\
\hline FES-0083 & темный & не анализируется \\
\hline FES-0084 & темный & не анализируется \\
\hline FES-0085 & темный & темные \\
\hline FES-0086 & темный & не анализируется \\
\hline FES-0087 & темный & темные \\
\hline FES-0088 & темный & темные \\
\hline FES-0089 & темный & не анализируется \\
\hline FES-0090 & темный & не анализируется \\
\hline FES-0091 & темный & темные \\
\hline FES-0092 & темный & темные \\
\hline FES-0093 & темный & не анализируется \\
\hline FES-0094 & темный & не анализируется \\
\hline FES-0095 & темный & темные \\
\hline FES-0096 & темный & не анализируется \\
\hline FES-0097 & темный & темные \\
\hline FES-0098 & темный & не анализируется \\
\hline FES-0099 & темный & не анализируется \\
\hline FES-0100 & темный & промежуточные \\
\hline FES-0101 & темный & не анализируется \\
\hline FES-0102 & темный & не анализируется \\
\hline FES-0103 & темный & темные \\
\hline FES-0104 & темный & не анализируется \\
\hline FES-0105 & темный & не анализируется \\
\hline FES-0106 & темный & не анализируется \\
\hline FES-0107 & темный & не анализируется \\
\hline FES-0108 & темный & темные \\
\hline FES-0109 & темный & не анализируется \\
\hline FES-0110 & темный & промежуточные \\
\hline FES-0111 & темный & не анализируется \\
\hline FES-0112 & темный & промежуточные \\
\hline FES-0113 & темный & темные \\
\hline FES-0114 & темный & промежуточные \\
\hline FES-0115 & темный & темные \\
\hline FES-0116 & темный & промежуточные \\
\hline FES-0117 & темный & промежуточные \\
\hline FES-0118 & светлый & промежуточные \\
\hline FES-0119 & темный & не анализируется \\
\hline FES-0120 & светлый & промежуточные \\
\hline FES-0121 & светлый & не анализируется \\
\hline FES-0122 & темный & светлые \\
\hline FES-0123 & темный & промежуточные \\
\hline FES-0124 & светлый & светлые \\
\hline
\end{tabular}




\begin{tabular}{|l|l|c|}
\hline \multicolumn{1}{|c|}{ Образец } & Предсказанный цвет глаз & Предсказанный цвет волос \\
\hline FES-0125 & темный & не анализируется \\
\hline FES-0126 & темный & не анализируется \\
\hline FES-0127 & темный & промежуточные \\
\hline FES-0128 & темный & промежуточные \\
\hline FES-0129 & светлый & светлые \\
\hline FES-0130 & светлый & светлые \\
\hline FES-0131 & светлый & промежуточные \\
\hline FES-0132 & темный & промежуточные \\
\hline FES-0133 & светлый & светлые \\
\hline FES-0134 & светлый & промежуточные \\
\hline FES-0135 & светлый & светлые \\
\hline FES-0136 & светлый & не анализируется \\
\hline FES-0137 & светлый & не анализируется \\
\hline FES-0138 & светлый & светлые \\
\hline FES-0139 & светлый & не анализируется \\
\hline FES-0140 & светлый & рыжие \\
\hline FES-0141 & светлый & не анализируется \\
\hline FES-0142 & светлый & светлые \\
\hline FES-0143 & светлый & светлый \\
\hline FES-0144 & - & \\
\hline
\end{tabular}

выполненные в трех проекциях с соблюдением антропологических стандартов, представляют собой ценный ресурс для этого и последующих исследований, направленных на выявление ассоциаций отдельных фенотипических признаков с генетическими маркерами. В данном исследовании фотографии использовали для определения цвета глаз и цвета волос. Проведение фенотипирования тремя независимыми экспертами и наличие фотограсий для перепроверки (при необходимости) делают результаты этого исследования надежными и воспроизводимыми.

Для генотипирования из ряда предложенных наборов генетических маркеров мы воспользовались наиболее полной, современной и популярной системой HlrisPlex-S, хорошо себя зарекомендовавшей в исследованиях современных и древних популяций Западной Европы [8, 11, 17]. Сравнение реальных фенотипов (определенных по фотографиям) и фенотипов, предсказанных по генотипам, позволило оценить точность этой панели для популяций за пределами Западной Европы. Из ряда показателей качества предсказания (табл. 3) наибольший интерес представляет AUC, поскольку значения этого показателя опубликованы для результатов применения HIrisPlex на популяциях Западной Европы [16]. Поэтому мы смогли напрямую сравнить эффективность этой системы для популяций Западной Европы и России.

В целом значения показателей качества предикции, полученные для большинства классов (см. табл. 3), оказались достаточно велики (0,6-0,9), чтобы использование предикции по HlrisPlex было обоснованным и для российских популяций. Ни одна система предикции фенотипа по генотипу не может претендовать на стопроцентную точность, и показатели HIrisPlex даже в Западной Европе не по всем классам превышают 0,9. Поэтому в целом мы считаем, что проверка HlrisPlex на популяциях России продемонстрировала работоспособность этой системы и удовлетворительные значения точности предсказания. В то же время точность предсказания для популяций России все же ниже, чем для популяций Западной Европы (в среднем 0,8 для России и 0,9 для Западной Европы). Поэтому мы считаем, что HirisPlex может быть использована для российских популяций, но рекомендуем при интерпретации результатов учитывать обнаруженное нами снижение показателей точности.

В нашем исследовании российские популяции были сгруппированы в две региональные базы данных: Европейская часть России и Сибирь. Предыдущие популяционногенетические исследования [18, 19] продемонстрировали, что эти метапопуляции контрастны по генетическому происхождению. Они оказались контрастными и по качеству предикции фенотипов, значительно сниженной для Сибири (см. табл. 4). Исходные данные (см. табл. 1 и 5) показывают, что HIrisPlex предсказывает темные глаза практически для всех сибирских образцов, тогда как у некоторых представителей сибирских народов цвет глаз определен как светлый (даже с учетом условности границы между светлыми и промежуточными оттенками цвет глаз этих индивидов в любом случае не темный, как предсказывает HlrisPlex). Можно предполагать, что светлый цвет глаз, изредка встречающийся у представителей коренных народов Сибири, связан с иными аллелями (возможно, и с иными генами), чем у европейцев, и именно поэтому разработанная на данных о западных европейцах панель не может корректно предсказать светлый (не темный) цвет глаз в этих популяциях. Некоторое снижение показателей точности на популяциях Европейской части России может иметь ту же природу, но, поскольку генетически эти популяции намного ближе к популяциям Западной Европы, то особенности спектра аллелей и, соответственно, снижения точности предикции выражены не так заметно. Это открывает перспективу проведения дополнительных исследований на популяциях России, направленных на 
поиск дополнительных генетических маркеров, улучшающих предикцию фенотипов пигментации по генотипу.

\section{ВЫВОДЫ}

Проведенный анализ корреляции генотипа и фенотипов пигментации волос и глаз в популяциях России на основе широко используемой панели HIrisPlex-S в целом подтвердил эффективность применения классической HirisPlex-S-панели для этих ранее не изученных популяций, хотя ее точность оказалась ниже, чем для групп западноевропейцев, для которых данный классисикатор был разработан. Снижение точности для популяций Европейской части России не так велико (например, с 0,94 до 0,89), как для популяций Сибири. Это снижение может быть обусловлено влиянием популяционно-специфических SNP, которые представлены в популяциях Северной Евразии, но редки в Западной Европе и поэтому не вошли в панель HIrisPlex-S.

\section{Литература}

1. Bouakaze C, Keyser C, Crubezy E, Montagnon D, Ludes B. Pigment phenotype and biogeographical ancestry from ancient skeletal remains: inferences from multiplexed autosomal SNP analysis. Int J Legal Med. 2009; 123 (4): 315-25.

2. Branicki W, Brudnik U, Kupiec T, Wolanska-Nowak P, Szczerbinska A, Wojas-Pelc A. Association of polymorphic sites in the OCA2 gene with eye colour using the tree scanning method. Ann Hum Genet. 2008; 72 (Pt 2): 184-92.

3. Candille SI, Absher DM, Beleza S, Bauchet M, McEvoy B, Garrison NA et al. Genome-wide association studies of quantitatively measured skin, hair, and eye pigmentation in four European populations. PLoS One. 2012; 7 (10): e48294.

4. Han J, Kraft P, Nan H, Guo Q, Chen C, Qureshi A, et al. A genomewide association study identifies novel alleles associated with hair color and skin pigmentation. PLoS Genet. 2008; 4 (5): e1000074.

5. Lippert C, Sabatini R, Maher MC, Kang EY, Lee S, Arikan O, et al. Identification of individuals by trait prediction using wholegenome sequencing data. Proc Natl Acad Sci USA. 2017; 114 (38): 10166-71.

6. Liu F, van Duijn K, Vingerling JR, Hofman A, Uitterlinden AG, Janssens AC, et al. Eye color and the prediction of complex phenotypes from genotypes. Curr Biol. 2009; 19 (5): R192-3.

7. Maronas O, Sochtig J, Ruiz Y, Phillips C, Carracedo A, Lareu MV. The genetics of skin, hair, and eye color variation and its relevance to forensic pigmentation predictive tests. Forensic Sci Rev. 2015; 27 (1): 13-40.

8. Walsh S, Chaitanya L, Clarisse L, Wirken L, Draus-Barini J, Kovatsi $\mathrm{L}$, et al. Developmental validation of the HirisPlex system: DNA-based eye and hair colour prediction for forensic and anthropological usage. Forensic Sci Int Genet. 2014; 9: 150-61.

9. Walsh S, Kayser M. A Practical Guide to the HlrisPlex System: Simultaneous Prediction of Eye and Hair Color from DNA. Methods Mol Biol. 2016; (1420): 213-31.

10. Walsh S, Liu F, Wollstein A, Kovatsi L, Ralf A, Kosiniak-Kamysz A, et al. The HlrisPlex system for simultaneous prediction of hair and eye colour from DNA. Forensic Sci Int Genet. 2013; 7 (1): 98-115.

\section{References}

1. Bouakaze C, Keyser C, Crubezy E, Montagnon D, Ludes B Pigment phenotype and biogeographical ancestry from ancient skeletal remains: inferences from multiplexed autosomal SNP analysis. Int J Legal Med. 2009; 123 (4): 315-25.

2. Branicki W, Brudnik U, Kupiec T, Wolanska-Nowak P, Szczerbinska A, Wojas-Pelc A. Association of polymorphic sites in the OCA2 gene with eye colour using the tree scanning method. Ann Hum Genet. 2008; 72 (Pt 2): 184-92.

3. Candille SI, Absher DM, Beleza S, Bauchet M, McEvoy B, Garrison NA, et al. Genome-wide association studies of quantitatively measured skin, hair, and eye pigmentation in four European populations. PLoS One. 2012; 7 (10): e48294.

4. Han J, Kraft P, Nan H, Guo Q, Chen C, Qureshi A, et al. A genomewide association study identifies novel alleles associated with hair color and skin pigmentation. PLoS Genet. 2008; 4 (5): e1000074.

5. Lippert C, Sabatini R, Maher MC, Kang EY, Lee S, Arikan O, et
11. Chaitanya L, Breslin K, Zuñiga S, Wirken L, Pośpiech E, KuklaBartoszek M, et al. The HlrisPlex-S system for eye, hair and skin colour prediction from DNA: Introduction and forensic developmental validation. Forensic Sci Int Genet. 2018; (35): 123-35.

12. Pagani L, Lawson DJ, Jagoda E, Mörseburg A, Eriksson A, Mitt M, et al. Genomic analyses inform on migration events during the peopling of Eurasia. Nature. 2016 Oct 13; 538 (7624): 238-42. DOI: 10.1038/nature19792.

13. Балановская Е. В., Жабагин М. К., Агджоян А. Т., Чухряева М. И., Маркина Н. В., Балаганская О. А. и др. Популяционные биобанки: принципы организации и перспективы применения в геногеограсии и персонализированной медицине. Генетика. 2016; (12): 1371-87.

14. Powell R, Gannon F. Purification of DNA by phenolextraction and ethanol precipitation. Practical Approach Series. Oxford: Oxford University Press, 2002.

15. Chang CC, Chow CC, Tellier LCAM, Vattikuti S, Purcell SM, Lee JJ. Second-generation PLINK: rising to the challenge of larger and richer datasets. GigaScience. 2015 December; 4 (1): s13742-015-0047-8. DOI: 10.1186/s13742-015-0047-8.

16. Department of Genetic Identification of Erasmus MC. HirisPlex-S Eye, Hair and Skin Colour DNA Phenotyping Webtool. [software]. Available from: https://hirisplex.erasmusmc.nl/.

17. Draus-Barini J, Walsh S, Pospiech E, Kupiec T, Glab H, Branicki W, et al. Bona fide colour: DNA prediction of human eye and hair colour from ancient and contemporary skeletal remains. Investigative Genetics. 2013 January; (4): 3. DOI: 10.1186/2041-2223-4-3.

18. Jeong C, Balanovsky O, Lukianova E, Kahbatkyzy N, Flegontov P, Zaporozhchenko $\mathrm{V}$, et al. The genetic history of admixture across inner Eurasia. Nat Ecol Evol. 2019 Jun; 3 (6): 966-76. DOI: 10.1038/s41559-019-0878-2.

19. Triska P, Chekanov N, Stepanov V, Khusnutdinova EK, Kumar GPA, Akhmetova V, et al. Between Lake Baikal and the Baltic Sea: genomic history of the gateway to Europe. BMC Genet. 2017 Dec 28; 18 (Suppl 1): 110. DOI: 10.1186/s12863-017-0578-3. al. Identification of individuals by trait prediction using wholegenome sequencing data. Proc Natl Acad Sci USA. 2017; 114 (38): 10166-71.

6. Liu F, van Duijn K, Vingerling JR, Hofman A, Uitterlinden AG, Janssens $A C$, et al. Eye color and the prediction of complex phenotypes from genotypes. Curr Biol. 2009; 19 (5): R192-3.

7. Maronas O, Sochtig J, Ruiz Y, Phillips C, Carracedo A, Lareu MV. The genetics of skin, hair, and eye color variation and its relevance to forensic pigmentation predictive tests. Forensic Sci Rev. 2015; 27 (1): 13-40.

8. Walsh S, Chaitanya L, Clarisse L, Wirken L, Draus-Barini J, Kovatsi L, et al. Developmental validation of the HlrisPlex system: DNA-based eye and hair colour prediction for forensic and anthropological usage. Forensic Sci Int Genet. 2014; 9: 150-61.

9. Walsh S, Kayser M. A Practical Guide to the HlrisPlex System: Simultaneous Prediction of Eye and Hair Color from DNA. 
Methods Mol Biol. 2016; (1420): 213-31.

10. Walsh S, Liu F, Wollstein A, Kovatsi L, Ralf A, Kosiniak-Kamysz A, et al. The HirisPlex system for simultaneous prediction of hair and eye colour from DNA. Forensic Sci Int Genet. 2013; 7 (1): 98-115.

11. Chaitanya L, Breslin K, Zuñiga S, Wirken L, Pośpiech E, KuklaBartoszek M, et al. The HlrisPlex-S system for eye, hair and skin colour prediction from DNA: Introduction and forensic developmental validation. Forensic Sci Int Genet. 2018; (35): 123-35.

12. Pagani L, Lawson DJ, Jagoda E, Mörseburg A, Eriksson A, Mitt M, et al. Genomic analyses inform on migration events during the peopling of Eurasia. Nature. 2016 Oct 13; 538 (7624): 238-42. DOI: 10.1038/nature19792.

13. Balanovska EV, ZHabagin MK, Agdzhoyan AT, CHukhryayeva MI Markina NV, Balaganskaya OA, et al. Populyatsionnyye biobanki: printsipy organizatsii i perspektivy primeneniya $\vee$ genogeografii personalizirovannoy meditsine. Genetika. 2016; (12): 1371-87. Russian.

14. Powell R, Gannon F. Purification of DNA by phenolextraction and ethanol precipitation. Practical Approach Series. Oxford: Oxford University Press, 2002
15. Chang CC, Chow CC, Tellier LCAM, Vattikuti S, Purcell SM, Lee JJ. Second-generation PLINK: rising to the challenge of larger and richer datasets. GigaScience. 2015 December; 4 (1): s13742-015-0047-8. DOI: 10.1186/s13742-015-0047-8.

16. Department of Genetic Identification of Erasmus MC. HlrisPlex-S Eye, Hair and Skin Colour DNA Phenotyping Webtool. [software]. Available from: https://hirisplex.erasmusmc.nl/.

17. Draus-Barini J, Walsh S, Pospiech E, Kupiec T, Glab H, Branicki W, et al. Bona fide colour: DNA prediction of human eye and hair colour from ancient and contemporary skeletal remains. Investigative Genetics. 2013 January; (4): 3. DOI: 10.1186/2041-2223-4-3.

18. Jeong C, Balanovsky O, Lukianova E, Kahbatkyzy N, Flegontov P, Zaporozhchenko $\mathrm{V}$, et al. The genetic history of admixture across inner Eurasia. Nat Ecol Evol. 2019 Jun; 3 (6): 966-76. DOl: 10.1038/s41559-019-0878-2.

19. Triska P, Chekanov N, Stepanov V, Khusnutdinova EK, Kumar GPA, Akhmetova V, et al. Between Lake Baikal and the Baltic Sea: genomic history of the gateway to Europe. BMC Genet. 2017 Dec 28; 18 (Suppl 1): 110. DOl: 10.1186/s12863-017-0578-3. 